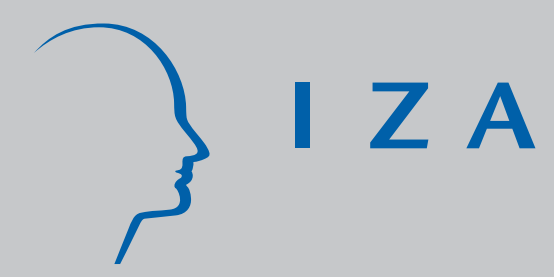

IZADP No. 1537

Pension Incomes in the European Union: Policy Reform Strategies in Comparative Perspective

Daniela Mantovani

Fotis Papadopoul os

Holly Sutherland

PanosTsakloglou

March 2005 


\title{
Pension Incomes in the European Union: Policy Reform Strategies in Comparative Perspective
}

\author{
Daniela Mantovani \\ University of Cambridge and Prometeia \\ Fotis Papadopoulos \\ Athens University of Economics and Business \\ Holly Sutherland \\ ISER, University of Essex \\ Panos Tsakloglou \\ Athens University of Economics and Business \\ and IZA Bonn
}

Discussion Paper No. 1537

March 2005

\author{
IZA \\ P.O. Box 7240 \\ 53072 Bonn \\ Germany \\ Phone: +49-228-3894-0 \\ Fax: +49-228-3894-180 \\ Email: iza@iza.org
}

\begin{abstract}
Any opinions expressed here are those of the author(s) and not those of the institute. Research disseminated by IZA may include views on policy, but the institute itself takes no institutional policy positions.

The Institute for the Study of Labor (IZA) in Bonn is a local and virtual international research center and a place of communication between science, politics and business. IZA is an independent nonprofit company supported by Deutsche Post World Net. The center is associated with the University of Bonn and offers a stimulating research environment through its research networks, research support, and visitors and doctoral programs. IZA engages in (i) original and internationally competitive research in all fields of labor economics, (ii) development of policy concepts, and (iii) dissemination of research results and concepts to the interested public.
\end{abstract}

IZA Discussion Papers often represent preliminary work and are circulated to encourage discussion. Citation of such a paper should account for its provisional character. A revised version may be available directly from the author. 


\section{ABSTRACT}

\section{Pension Incomes in the European Union: Policy Reform Strategies in Comparative Perspective*}

This paper considers the effects on current pensioner incomes of reforms designed to improve the long-term sustainability of public pension systems in the European Union. We use EUROMOD to simulate a set of common illustrative reforms for four countries selected on the basis of their diverse pension systems and patterns of poverty among the elderly: Denmark, Germany, Italy and the UK. The variations in fiscal and distributive effects on the one hand suggest that different paths for reform are necessary in order to achieve common objectives across countries, and on the other provide indications of the appropriate directions for reform in each case.

JEL Classification: $\quad$ C81, I30, H55

Keywords: pensions, European Union, microsimulation

Corresponding author:

Panos Tsakloglou

Department of International and European Economic Studies

Athens University of Economics and Business

76 Patission Street

Athens 10434

Greece

Email: panos@aueb.gr

\footnotetext{
* Acknowledgements: This paper was written as part of the MICRESA (Micro Analysis of the European Social Agenda) project, financed by the Improving Human Potential programme of the European Commission (SERD-2001-00099). We are indebted to our present and former colleagues Herwig Immervoll, Christine Lietz and Cathal O'Donoghue for their invaluable contributions to the construction of the EUROMOD. Thanks are due to participants of the International Microsimulation Conference on Population Ageing and Health, Canberra, December 2003, the MICRESA project meeting, Lisbon, May 2004, a seminar at the University of Sheffield, and to Herwig Immervoll and Manos Matsaganis for helpful comments on earlier versions of this paper. The views expressed in this paper, as well as any errors, are the responsibilities of the authors. In particular, this applies to the interpretation of model results and any errors in its use. EUROMOD is continually being improved and updated and the results presented here represent the best available at the time of writing. Part of the research was carried out while Panos Tsakloglou was a visiting Senior Research Fellow at the Hellenic Observatory of the LSE. He wishes to thank the members of the Observatory for their hospitality.

EUROMOD relies on micro-data from twelve different sources for fifteen countries. In this paper we make use of the European Community Household Panel (ECHP) User Data Base made available by Eurostat; the public use version of the German Socio Economic Panel Study (GSOEP) made available by the German Institute for Economic Research (DIW), Berlin; the Survey of Household Income and Wealth (SHIW95) made available by the Bank of Italy; and the Family Expenditure Survey (FES), made available by the UK Office for National Statistics (ONS) through the Data Archive. Material from the FES is Crown Copyright and is used by permission. Neither the ONS nor the Data Archive bear any responsibility for the analysis or interpretation of the data reported here. An equivalent disclaimer applies for all other data sources and their respective providers cited in this acknowledgement.
} 


\section{Pension incomes in the European Union: policy reform strategies in comparative perspective}

\section{Introduction}

According to many commentators, one of the most important problems facing the majority of the European Union (EU) Member States in the coming years is related to the rapid ageing of their populations and the concomitant difficulties in the ability of their social protection systems to maintain the living standards of their senior citizens. In most EU countries "defined benefit" Pay-As-You-Go pension systems are in operation. With the anticipated decline in the ratio of workers to pensioners, serious doubts have been expressed regarding their sustainability. Broadly speaking, two types of policies have been recommended in the public discourse in order to avoid the collapse of the system: (i) policies aiming to move the pensions systems closer to "defined contributions" rather than "defined benefits" and/or promote private insurance schemes and (ii) policies aiming to modify the existing arrangements, without altering their main characteristics. The most important of the policy recommendations of the second type come under the headings of (a) Delayed retirement, (b) Lower replacement rates, (c) Increased social insurance contributions rates, and (d) Introduction or extension of systems of minimum (solidarity) pensions in order to avoid situations of extreme poverty and deprivation among the senior citizens. Our paper focuses on proposals aiming to modify existing arrangements, rather than altering the very nature of the pension systems.

While studies examining the fiscal consequences of these types of proposal can be found in the literature, ${ }^{1}$ relatively little detailed attention has been paid to the likely distributional impact of these recommendations, especially in the short-run. This is an important gap, since, as the experience of many EU countries suggests. the short-term political acceptability and longer-term sustainability of the reform proposals may depend primarily on distributional rather than fiscal considerations. Our paper attempts to fill this gap by providing estimates of the likely short-term effects of policy reforms of the type (b)-(d), if such reforms were to be introduced in the existing social protection systems of four European countries representing different "welfare-state regimes" [Esping-Andersen (1990), Ferrera (1996)]: Denmark (“social-democratic”), Germany (“corporatist”), Italy (“southern”) and the UK ("liberal"). For the purposes of our analysis we use EUROMOD, a detailed static microsimulation model covering all 15 (pre-May 2004) EU Member States. As well as the fiscal implications of the reforms, emphasis is placed on their likely impact on the gap between the elderly and non-elderly and on the poverty status of the two groups. Detailed comparisons are performed under alternative scenaria and similarities and differences across countries are identified.

The remainder of the paper is organised as follows. Section 2 provides a detailed description of the current situation of elderly and non-elderly in EU countries using data from the European Community Household Panel (ECHP) and estimates derived using EUROMOD. Section 3 discusses the use of static micro-simulation methods to evaluate pension reforms. Section 4 analyses the separate effects of three policy reforms: the introduction (or enhancement) of systems of minimum pensions, lower replacement rates and increased social

See, for example, Feldstein and Siebert (2002) and the references cited there. 
insurance contributions rates. Section 5 describes the impact of combinations of the above reforms. Section 6 concludes the paper.

\section{Incomes and poverty of elderly persons in the EU}

One of the main objectives of most pension systems is to provide elderly citizens with sufficiently high incomes, so that their living standards do not lag seriously behind those of the rest of the population, and so that they do not live in poverty. Therefore, we start by examining the current situation in the EU in these respects. Table 1 provides a snapshot picture of the income position of the elderly (persons aged 65+) in the 15 (pre- May 2004) EU Member States using the information from the 2000 wave (with incomes for 1999), of the European Community Household Panel (ECHP). ${ }^{2}$ The first row shows that the share of elderly persons living in private households varies between $11.1 \%$ in Ireland and $19.3 \%$ in Greece. This variation depends both on the demographic structure of the population and on institutional arrangements for care of the elderly. ${ }^{3}$ The second line reports the ratio of the mean equivalent disposable income of the elderly to the mean equivalent disposable income of the non-elderly. ${ }^{4}$ In most countries the percentage is between $80 \%$ and $100 \%$. It is lowest in Denmark with a ratio of $78 \%$ while in the Netherlands the average income of the elderly is $4 \%$ higher than that of the non-elderly. Although in most countries the elderly lag behind the non-elderly, in most of them the differences are not as large as the differences observed ten or fifteen years ago [ISSAS (1990), Hagenaars et al (1994), Tsakloglou (1996a, 1996b)]. ${ }^{5}$

While in aggregate the incomes of the elderly are reasonably close to those of the working aged in all countries, there is much more variation in the extent to which poverty occurs among the elderly, compared with the rest of the population. In four countries (the Netherlands, Luxembourg, Italy and Sweden) the poverty rate of the elderly is lower than that of the non-elderly - by a very large margin in the case of the Netherlands - while in Germany there is no difference in the poverty rates of the two groups. On the contrary, in Austria, Belgium, Finland, Ireland and, especially, Denmark, the poverty rates of the elderly are more than twice as high as those of the non-elderly. As a result, the share of the elderly in aggregate poverty varies enormously; from $3.5 \%$ in the Netherlands to $40.2 \%$ in Denmark. ${ }^{6}$ However, since in many countries a considerable proportion of the elderly receive a pension that is slightly lower than the poverty line, the elderly may be poor but, on average, they may be less

2 The ECHP is an ambitious effort at collecting information on the living standards of the households of the EU member-states using common definitions, information collection methods and editing procedures. It contains detailed information on incomes, socio-economic characteristics, housing amenities, consumer durables, social relations, employment conditions, health status, subjective evaluation of well-being, etc. For a detailed description see Eurostat (1996); for a critical appraisal see Peracchi (2002).

3 ECHP excludes people living in institutions such as old age homes but the extent to which this occurs among the elderly is not the same in all countries.

4 The "income ratio" compares equivalised household incomes across individuals. Following Eurostat's methodology, throughout the paper we use the "modified OECD” equivalence scale, which assigns a weight of 1 to the household head, weights of 0.5 to every other adult in the household and 0.3 to each child (person aged below 14) in the household.

5 The estimates reported in Table 1 are not strictly comparable with the estimates of these studies, primarily because the latter's concept of resources includes incomes in-kind.

$6 \quad$ It is worth noting that alternative sources of micro-data may show other patterns. For example, the 2001

Danish Law Model database (European Commission, 2003; Table 2) gives an at risk of poverty rate of $8 \%$ for non-elderly adults - which compares well with the ECHP estimate for all non-elderly in Table 1 . However the corresponding estimate for the elderly is $24 \%$, much lower than the ECHP figure of $31 \%$. 
likely than the non-elderly poor to be located far below the poverty line. Table 1 provides estimates of the poverty index of Foster et al (1984). ${ }^{7}$ In seven countries (Spain, Finland, Italy, Luxembourg, the Netherlands, Sweden and the UK) the estimates for the elderly are lower - sometimes substantially so - than the estimates for the non-elderly. In three countries the estimates for the two groups are very close (Germany, France and Portugal) and only in five countries (Austria, Belgium, Denmark, Greece and Ireland) the estimates for the elderly are clearly higher than those for the non-elderly. Once again, the contribution of the elderly to the aggregate poverty index varies considerably across countries; from around $2 \%$ in the Netherlands and Sweden to almost $40 \%$ in Denmark.

Clearly, an important part of the explanation for poverty among the elderly lies in the pension systems. The final row of table 1 shows the share of pensions in the incomes of the elderly, at the individual level. Again the aggregate picture is one of relative uniformity with the share of pensions in the incomes of those aged over 64 varying between $81 \%$ and $91 \%$ in all countries apart from the UK (76\%). Thus to explain the widely diverging patterns of poverty among the elderly we must investigate what lies behind these averages and the nature of the pension systems themselves. For example, high levels of poverty intensity indicate that pension coverage may be incomplete, or that the levels of some pensions are very low. High rates of poverty with low intensity suggest that the general level of pension is too low. Devising reform strategies involves taking existing inadequacies of level, structure and coverage of existing systems into account.

In the next step we focus on the four countries of interest, using EUROMOD, a taxbenefit model for the European Union [see Immervoll et al. (1999) for a general description]. Tax-benefit models calculate disposable income for each household in a representative set of micro-data. The datasets used as the basis for this paper are listed in Appendix 1. They were chosen on the grounds that they provide the best quality input for a tax-benefit model and are at the same time available and accessible to an international scientific project. Although they include data collected at various points around the mid-1990s, they have all been adjusted to 1998 prices and incomes and, where necessary gross incomes have been imputed from net [Immervoll and O'Donoghue (2001)]. The calculation of household disposable income is made up of elements of gross income taken (or imputed) from the survey data combined with elements of income - taxes and benefits - that are simulated by the model. For the purposes of the paper, the calculations are performed once for the 1998 tax-benefit system, and again for each alternative scenario. The first round effect of the simulated change is the arithmetic difference in the "before" and "after" calculations.

7 We set the poverty aversion parameter of the index at $a=2(F G T(2))$. For this value, the index is sensitive to both the distance of the average poor person from the poverty line and the extent of inequality among the poor. Since, in absolute terms, the estimates of the FGT(2) are very small, for expositional purposes in the tables of the paper they are multiplied by 100 . 
Table 1. Relative income position of elderly people in EU countries (ECHP, 2000)

\begin{tabular}{|c|c|c|c|c|c|c|c|c|c|c|c|c|c|c|c|}
\hline & $\mathrm{AT}$ & $\mathrm{BE}$ & DK & $\mathrm{D}$ & $\mathrm{E}$ & EL & FIN & FR & IRL & IT & LUX & NL & PT & SWE & UK \\
\hline Population share of the elderly (65+) \% & 15.2 & 16.8 & 14.8 & 17.6 & 16.8 & 19.3 & 14.7 & 16.2 & 11.1 & 16.7 & 14.8 & 12.8 & 14.9 & 15.5 & 18.1 \\
\hline Income ratio $^{1}$ & 0.90 & 0.80 & 0.78 & 0.97 & 0.89 & 0.84 & 0.83 & 0.94 & 0.81 & 1.00 & 0.95 & 1.04 & 0.83 & 0.91 & 0.83 \\
\hline Poverty rate of elderly \% & 23.1 & 23.7 & 31.3 & 10.7 & 18.6 & 31.2 & 19.4 & 18.6 & 42.1 & 13.2 & 8.7 & 2.8 & 32.7 & 9.9 & 24.1 \\
\hline Poverty rate of non-elderly \% & 9.6 & 11.4 & 8.0 & 10.7 & 17.9 & 17.2 & 9.4 & 15.0 & 17.4 & 19.5 & 12.4 & 11.6 & 18.8 & 11.3 & 17.4 \\
\hline Contribution of elderly to aggr. pov. rate \% & 30.3 & 29.4 & 40.2 & 17.6 & 17.4 & 30.2 & 26.2 & 19.4 & 23.2 & 12.0 & 10.8 & 3.5 & 23.4 & 14.0 & 23.4 \\
\hline FGT(a=2) elderly $(* 100)^{2}$ & 2.10 & 1.95 & 2.40 & 1.26 & 1.28 & 4.25 & 0.48 & 1.42 & 2.59 & 1.09 & 0.27 & 0.19 & 2.97 & 0.24 & 2.12 \\
\hline FGT(a=2) non-elderly (*100) & 0.90 & 1.28 & 0.66 & 1.22 & 2.84 & 2.83 & 0.91 & 1.43 & 1.78 & 3.38 & 0.69 & 1.50 & 2.94 & 2.13 & 2.70 \\
\hline Contribution of elderly to FGT(a=2) \% & 29.5 & 23.6 & 38.7 & 18.2 & 8.4 & 26.4 & 8.3 & 16.1 & 15.4 & 6.0 & 6.3 & 1.9 & 15.0 & 2.0 & 14.8 \\
\hline Share of pensions in elderly incomes ${ }^{3} \%$ & 85.0 & 86.1 & 81.0 & 90.1 & 86.4 & 83.9 & 86.4 & 90.6 & 80.4 & 87.8 & 85.0 & 90.9 & 84.5 & 90.2 & 76.9 \\
\hline
\end{tabular}

\footnotetext{
Source: ECHP (2000 - own calculations)

1. Income ratio: mean equivalent income of persons aged 65+/ mean equivalent income of persons aged below 65

2. FGT $(\mathrm{a}=2)$ : Foster, Greer and Thorebecke index of poverty using poverty aversion parameter $\mathrm{a}=2.0(\mathrm{x} 100)$

3. Pensions are defined as in ECHP variable PI132: Old age pension basic schemes, Old age pension supplementary schemes, Old age pension personal schemes, Old age means tested welfare schemes, Early retirement schemes, Other old age related schemes or benefits, Widows pension basic schemes, Widows pension supplementary schemes, Widows pension personal schemes, Widows means tested welfare schemes, Other widows benefits, Orphan’s pension/allowance.
} 
Table 2 provides some background information about the 1998 pension systems. The statutory retirement age is usually 65, except for women in UK and Italy (60), and for all retirees in Denmark (67). In the main part of our analysis we consider people aged 65 and over (the "elderly") which, in the Danish case includes some people not yet eligible. In all countries, some of the elderly do not receive a pension. In addition, some pension recipients are not past retirement age. However, we do not consider early retirement in this paper, although this is a key issue for the sustainability of some pension systems: notably that of Italy among the four countries that we consider. ${ }^{8}$

Table 2. State pension incomes in 1998 in four EU countries: some key figures

\begin{tabular}{|c|c|c|c|c|}
\hline & Denmark & Germany & Italy & UK \\
\hline Pension age $^{1}$ & $67(65)$ & 65 & $65 / 60$ & $65 / 60$ \\
\hline $\begin{array}{l}\text { Maximum public pension for a } \\
\text { single person }{ }^{2}\end{array}$ & 14,726 & No max. & No max. & 13,666 \\
\hline $\begin{array}{l}\text { Minimum public pension for a } \\
\text { single person }\end{array}$ & 6,276 & No min. & 4,684 & $4,784 / 1,198$ \\
\hline $\begin{array}{l}\text { Minimum income level, single } \\
\text { person age } 70\end{array}$ & $\begin{array}{l}\text { No min. } \\
\text { income }\end{array}$ & $\begin{array}{c}3,829 \\
\text { (average) }\end{array}$ & 1,216 & 5,088 \\
\hline Poverty line (single person) ${ }^{4}$ & 10,263 & 8,346 & 6,275 & 7,747 \\
\hline $\begin{array}{l}\text { \% elderly with public pension } \\
\text { income }^{5}\end{array}$ & 88 & 90 & 81 & 98 \\
\hline $\begin{array}{l}\% \text { elderly below the poverty line } \\
\text { with public pension income }\end{array}$ & 89 & 74 & 76 & 98 \\
\hline $\begin{array}{l}\% \text { elderly with private pension } \\
\text { income }\end{array}$ & $\mathrm{n} / \mathrm{a}$ & 21 & 1 & 54 \\
\hline $\begin{array}{l}\% \text { employed people aged }<65 \\
\text { paying state pension contributions }\end{array}$ & 100 & 77 & 99 & 87 \\
\hline Income ratio & 0.67 & 0.92 & 1.00 & 0.81 \\
\hline
\end{tabular}

Sources: EUROMOD, unless otherwise specified; n/a - not available

Notes: Except where otherwise stated money amounts are in 1998 Euro per year using the following exchange rates per Euro (December 31 1998) DK: 7.4587, DE: 1.9558, IT: 1936.3,UK: 0.7032. These exchange rates have not been adjusted for purchasing power differences. Money amounts in this table should be compared within columns, not between columns. However, even information within columns has been drawn from a variety of sources for a range of years and is not necessarily fully comparable.

1. Economic Policy Committee (2002) Table 3.2. Men/women; (after 1998 reforms)

2. For DK this includes maximum old age pension plus maximum ATP; UK includes basic pension plus maximum SERPS

3. "Minimum pension" has different meanings in different contexts. For UK this is the full basic state pension/minimum basic state pension for those with minimum contributions leading to a pension. For DK it is the full "basic amount" of the old age pension for someone meeting the residency requirement in full. A pensioner with no other income would be entitled to a means-tested addition. For Italy it is the minimum payable to a person with a contribution record

4. 60\% median equivalised income in 1998 Euro per year. Calculated using EUROMOD (see Mantovani and Sutherland, 2003; appendix 2)

5. As defined in section 4.1.

8 Using EUROMOD it is difficult to model delayed retirement since its database does not contain the information necessary to model the counterfactual of later retirement. 
Three countries have effective minimum levels of state pensions. These, as well as existing minimum income levels, are below the respective national poverty lines (calculated for a single person). Thus, it is not surprising that, as shown in Table 3, there are considerable proportions of elderly living below the poverty line in all four countries.

Table 3. Poverty indicators for 1998 in four EU countries: some key baseline figures from EUROMOD

\begin{tabular}{lcccr}
\hline & Denmark & Germany & Italy & UK \\
\hline Poverty rate (all) & 11.4 & 9.9 & 20.1 & 19.9 \\
Poverty rate (65+) & 31.0 & 13.9 & 18.0 & 22.6 \\
FGT (a=2) (all) & 0.973 & 0.673 & 3.131 & 1.107 \\
FGT (a=2) (65+) & 0.483 & 0.978 & 1.189 & 0.730 \\
\hline
\end{tabular}

Source: EUROMOD

Notes: Poverty is defined as income below $60 \%$ of median equivalised household disposable income, using the modified OECD equivalence scale.

These indicators of poverty before any reforms, as estimated using EUROMOD, provide a "baseline" picture against which to measure the effect of reforms. ${ }^{9}$ They confirm the picture provided by the ECHP data in Table 1 that while the population poverty headcount is lower in Denmark and Germany than in the other two countries, it is highest for the elderly in Denmark, followed by the UK and then Italy. On the other hand, intensity of poverty is lower for the elderly in the UK and Denmark, but higher in Germany. In fact, it is striking how the ranking of countries almost completely reverses when one compares the estimates of the poverty rate, which only takes into account the extent of poverty, and the FGT(2) which also takes into account the intensity of poverty (as well as the degree of inequality in the distribution of income among the poor). Table 2 shows that the coverage rates of pensions are much lower for the poor than for the population of elderly as a whole in Germany and Italy, suggesting that lack of coverage is at least a contributory factor to elderly poverty in these countries. On the other hand in Denmark and the UK coverage is just as good for the poor as for the elderly as a whole, suggesting that inadequate pensions levels are to blame for poverty among the elderly. It appears that pension and benefit systems are successful at either keeping the substantial majority of elderly people out of poverty altogether while allowing a minority to fall substantially below the poverty line or preventing most from falling far below the poverty line through near-comprehensive minimum pension or minimum income schemes, even though a considerable proportion of them are located below - but not far from - the poverty line. None of the systems considered here either completely fail or completely succeed on both grounds.

9 Naturally, due to different reference years, data sources and the fact that taxes and benefits in EUROMOD are simulated, a number of figures in Table 3 differ from the corresponding estimates of Table 1. See Mantovani and Sutherland (2003) for a discussion. One important source of difference is the treatment of non-take-up of means-tested benefits and pensions by pensioners. For simplicity, EUROMOD estimates assume complete take-up whereas, at least for the UK, there is evidence of considerable non-take-up (Hancock and Barker, 2005). While under 1998 policies this would not make much difference to the poverty rate as measured using the proportion in households below $60 \%$ of the median, poverty rates using lower poverty lines, or measures that take account of intensity such as FGT(2) would be expected to be underestimated using EUROMOD. 


\section{Evaluating alternative pension reforms}

Pension reform is necessarily a long-term process in several different senses. First, changes to financing arrangements and to the basis of eventual pension payments are likely to take at least one working life to reach maturity. Understanding the consequences for future pensioners - and indeed future contributors - of reforms made today is a crucial component of the process of evaluating alternative reform strategies. In addition to the obvious difficulties in predicting future social and economic conditions there are also uncertainties surrounding the extent of political consensus behind reforms. A particular reform package may be adopted at one point in time, but will be subject to change as material conditions - and political climate - shift over time. ${ }^{10}$ So, while it is clear that a dynamic analytical approach of some variety is necessary to evaluate the long-term consequences of pension reform, a short- term static approach is also informative, particularly in a comparative perspective. It allows us to focus on possible individual components of reform packages, taking the direction of reform from the longer term strategies. Through such an exercise we can identify potential winners and losers under alternative reform scenaria and gain a richer understanding of the underlying differences in current institutional arrangements and behavioural patterns of particular societies. As a result, we obtain a clearer picture of the specific challenges facing each country, of the appropriateness of particular reform strategies and, perhaps, get useful insights regarding the political feasibility of proposed policy changes.

In addition, we are able to focus on a somewhat different notion of "adequacy" than that highlighted in recent official European discussions. Rather than considering the ways to encourage greater saving and private pension provision, as a route to the achievement of adequate retirement incomes in the future, we consider how to protect and improve the level of pension income now, and through the coming period of reform. If political consensus for pension reform is to be achieved, and other EU goals in relation to social inclusion are to be met, then one important factor will be the extent to which the solidarity component of the evolving pension systems protects the incomes of current pensioners [World Bank (1994), Gillion et al (2000), ILO (2001)]. One factor in making acceptable the combination of higher contributions (or taxes) and lower average replacement rates for public pensions is a guarantee that minimum pensions will be maintained through time at an adequate level. Of course, the meaning of "adequate" is debatable, and under most criteria would be costly to finance. Moreover, it may be argued that the very existence of a guaranteed adequate level would reduce individual incentives to save for retirement. However, to make judgements about the appropriate balance between improving incentives and ensuring income security requires that one understands the costs and benefits of each strategy. This paper is intended as a contribution to such understanding.

The four countries we consider represent different types of pension systems facing different challenges. The German and Italian systems have at their heart an earnings-related contributory pay-as-you-go pension. The Italian system is supplemented by minimum pension schemes that are designed to make sure that pensioners with low entitlements under the earnings-related scheme receive at least a minimum level of pension. There is also a means-

10 In fact, some authors dispute the urgency of pension reform in OECD countries on economic grounds and claim that the reform agenda that is currently promoted by international organizations and implemented in a number of countries is primarily motivated by political considerations (Weller, 2004). 
tested social pension for elderly people without contributory pensions. The Danish system is based on a non-contributory residence-based tax-financed pension. There is a means-tested addition and also a, now compulsory, contributory pension that is not earnings-related (but depends on hours worked). The UK system has a contributory basic pension plus an earningsrelated contributory state pension that may be replaced by private provision. In all four countries there are regulated or incentivised private schemes. With the major exception of the UK, and to a smaller extent Germany, these schemes do not yet constitute a significant part of pension incomes for current pensioners. See Appendix 2 for more detail about current (1998) state pension schemes and contribution arrangements.

In the analysis which follows we focus on public pensions and their associated contribution systems. To some extent we ignore the parts of the state system that are effectively contracted out to private occupational schemes or to personal pension savings schemes, even where these are compulsory and regulated by the state, or where they are subsidised through tax incentives. The reason for this is that it is impossible to draw a common line for all EU systems that divides "public" pensions from "private". Any choice is to some extent arbitrary and here we make a choice based on pragmatic considerations. Using the data available to us we are unable to distinguish between all forms of quasi-public and private pensions and do not have sufficient information to calculate liability for private pension contributions. However, in the case of the UK ignoring state-subsidised private pensions would make that the remaining state pension provision appear to be very meagre, when compared with the other three systems. For many current pensioners, a significant source of pension income is from an occupational defined benefit scheme (in many respects similar to continental social insurance schemes and a major source of inequalities between elderly men and women in the UK, according to Bardasi and Jenkins (2004)). These pensioners (and their employers) have contracted out of the state earnings related scheme and paid lower contributions. So in what follows these pensions are included along with state pensions for the UK, but not for other countries (where they are much less significant). Thus, conclusions that we draw about the UK system relative to the other three should bear this departure from comparability in mind.

\section{Reform scenaria}

We consider three illustrative reforms, first individually and then in combination.

- Reform 1 is the introduction of a common minimum pension scheme in all four countries. The purpose of this is to strengthen the "solidarity" element of current systems with the aim of protecting pension incomes at some acceptable level, while other reforms take place.

We consider two alternative, stylised methods of paying for this minimum, placing the burden on the working and the retired population respectively:

- Reform 2 is an increase in the rate of the main tax or contribution paid by employees and self-employed which finances public pensions.

- Reform 3 is a proportional reduction in pensions in payment.

In each case we wish to consider the budgetary cost of the reform as well as the distributional consequences. In order to be able to compare across countries, we measure the 
cost of the reform in terms of the proportional change in aggregate household disposable income. This is not equivalent to the proportional change in the public budget. When comparing different schemes within countries, one can interpret the change in aggregate household income as being equivalent to the fiscal cost. However, when comparing across countries account must be taken of differing aggregate levels of income and different relative sizes of the tax and benefit systems.

Changes in poverty are assessed against the poverty line that corresponds to $60 \%$ of median equivalised disposable income in the baseline (pre-reform) scenario. The poverty line does not shift with changes in median incomes.

\subsection{Reform 1: A minimum pension}

In recent years, several European governments have introduced or strengthened existing minimum pension schemes. These schemes may be particularly useful in periods of pension reform, since they strengthen social solidarity and make the reforms more easily acceptable from a political point of view. In this reform scenario, the design of the scheme is as follows. The minimum is set at a common proportion of current national average earnings (20\%, 30\%, 40\% and 50\%). In the central scenario that will be analysed in detail in order to understand the mechanics of the reform, the proportion is set at $40 \%$. It is designed as an individual pension entitlement, guaranteeing that everyone aged 65 or more who has existing public pension rights will receive at least this level of pension income. Any resulting increase in pension is treated in the same way by the rest of the tax and benefit system as existing contributory pensions. Thus, the gain from the addition of the minimum pension may be withdrawn to some extent due to income taxation, contribution payments or reduction of income related benefits such as housing benefits. It is intended to be financed out of social contributions and so is only available to those who have made their own contributions. It does not guarantee a pension to all citizens over the age of 65 and does not improve the situation of those with no contributory rights. ${ }^{11}$ The amount of the payment is independent of the marital status of the pensioner and of the existence of any dependants. It is not income-tested, except against other pension income. This is defined as follows, for those aged 65+:

Denmark: all non-contributory and ATP pension income

Germany: all contributory pensions and survivors' benefits

Italy: all earnings-related pensions and survivors' benefits and all existing contributory minimum pension payments.

UK: basic state pension, widow's pension and SERPs and occupational "defined benefit" pensions.

As explained above, occupational (private) pensions are included for the UK because for many people these replace rather than supplement the state earnings related scheme. Omitting them from the eligibility test for the minimum pension, combined with the low level of the basic state pension, would result in very large proportions of pensioners - including some of those with the highest pension incomes - benefiting from the minimum.

11 See Atkinson et al (2002), Atkinson and Sutherland (1998) and Sutherland (1998) for illustrations of the effects of comprehensive minimum pension schemes that aim to cover all the elderly. 
The proportions of individuals aged 65+ in receipt of their own state pension income varies across the four countries (see Table 2). The treatment of married women without pension rights based on their own contributions also differs. In most countries, pension payments are independent of marital status (although in all contributory systems widows and widowers inherit some part of their spouse's contributory pension; in Denmark a widow/er has her/his own old age pension rights based on citizenship). In the UK couples receive a higher basic pension than single people even if the pension is only based on one set of contributions. It is paid partly to the "dependent" spouse. This makes it difficult to determine which individuals should have rights to the minimum under this scenario. To aid comparability across countries we assume in a second variant that UK women in receipt of a state pension at only the dependant's rate do not qualify for their own minimum pension. ${ }^{12}$

In all four countries, the great majority of the elderly live either alone or with their spouses. It should be noted that the implicit equivalence scale used here in the case of couples with two low-pension spouses is higher than the equivalence scale used for the purposes of poverty analysis. Thus, ceteris paribus, our scheme is likely to be more effective in fighting poverty among elderly (two-pension) couples than among single elderly persons. However, it is less likely to be effective for couples with only one pension entitlement between them.

Table 4 shows the level of the minimum pension corresponding to $40 \%$ of national average earnings before tax or employee contributions, and the aggregate effects of implementing it. First, in terms of nominal 1998 euro it is clear that the level of the minimum varies greatly. Adjusting for purchasing power differences narrows the range but does not eliminate it.

Table 4. Effects of a minimum pension set at $40 \%$ average gross earnings

\begin{tabular}{|c|c|c|c|c|c|}
\hline & Denmark & Germany & Italy & \multicolumn{2}{|c|}{$\mathbf{U K}^{1}$} \\
\hline $\begin{array}{l}\text { Minimum pension level: } \\
€ / \text { year }\end{array}$ & 13,208 & 11,668 & 7,056 & \multicolumn{2}{|c|}{10,675} \\
\hline PPS/year $^{2}$ & 10,678 & 10,978 & 8,005 & \multicolumn{2}{|c|}{9,909} \\
\hline$\%$ change & & & & variant 1 & variant 2 \\
\hline $\begin{array}{l}\text { Household disposable } \\
\text { income }\end{array}$ & 1.4 & 2.9 & 1.4 & 4.2 & 2.2 \\
\hline Benefits and state pensions & 7.5 & 9.9 & 5.9 & 22.2 & 11.7 \\
\hline Social contributions & 0.0 & 1.6 & 0.0 & 0.0 & 0.0 \\
\hline Taxes & 1.8 & 0.1 & 1.7 & 3.2 & 2.0 \\
\hline Poverty rate (age 65+) & -63.5 & -69.1 & -54.4 & -96.5 & -93.8 \\
\hline$\%$ affected (aged 65+) & 82.9 & 47.5 & 42.3 & 79.9 & 58.1 \\
\hline
\end{tabular}

Source: EUROMOD

1. Variant 1 allows married women to qualify on their own account based on pension income arising from their husbands' contributions; variant 2 removes eligibility on the basis of “dependent" pensions.

2. PPP conversion factors calculated by Eurostat for 1998 and provided in Dennis and Guio (2003).

12 This is in fact somewhat arbitrary because some of these women might have made their own contributions but are better off claiming a pension as their husband's dependant than in their own right. So the scheme most comparable to that in the other three countries is somewhere between the two variants. 
Under variant 1 incomes as a whole rise by $4.2 \%$ in the UK compared with $2.9 \%$ in Germany, and $1.4 \%$ in both Italy and Denmark. The second UK variant restricts eligibility for the minimum to those receiving a state pension based on their own contributions or those of a deceased spouse. This makes a large difference to the cost, reducing it to a $2.2 \%$ increase in disposable income, lower than the aggregate change in income for Germany. Further discussion concentrates on this more restrictive version of the scheme (although it should be noted that this treatment is not strictly comparable with that in the other three countries). In particular the inclusion of non-state pension income in other countries would reduce the cost to some extent. This is likely to be significant only in Germany where $21 \%$ of elderly receive some amount of this form of income (Table 2). However, it is interesting to note that there is very little difference in the impact on poverty in the UK using either of the variants, in spite of the large difference in cost. In fact both variants are sufficient to virtually eliminate elderly poverty in the UK.

The main effect on incomes is directly through the increase in pension income although in each country taxes (and in Germany, contributions) are levied on pensions making the net aggregate effect lower. In each country income from minimum income schemes is replaced to some extent by the minimum pension. The effects are small in Denmark, Germany and Italy where the cost of the gross minimum pension is $2-4 \%$ higher before taking account of withdrawal of social assistance, housing benefits and other minimum income schemes. In the UK the effect is much larger: $29 \%$ of the gross cost is compensated by a reduction in the cost of pensioner means-tested benefits.

The impact on poverty rates for the elderly is large with reductions of at least half in all countries. This leaves just $4.3 \%$ of elderly in poverty in Germany and $8.2 \%$ in Italy. The reduction of $64 \%$ or (19.7 percentage points) in Denmark from a high starting point of $31 \%$ (Table 3), leaves $11.4 \%$ of Danish elderly below the poverty line. The UK case is the most dramatic - all but $1.4 \%$ of elderly are taken out of poverty by the minimum pension under variant 2, a reduction of 94 percent (under variant 1 the poverty rate falls by $97 \%$ to $0.8 \%$ ). These effects depend partly on the size of the gains: how far existing pension incomes are below the new minimum level, and partly on the position of those with low pensions in the household income distribution. These are considered in turn.

Figure 1 shows that the distribution of the size of the net benefit varies considerably across countries. In Denmark a very large proportion of the population aged 65+ are net gainers (83\%). However, as many as $34 \%$ are gaining less than $10 \%$ of their (current) income. About the same proportion in the UK as in Denmark (47\% and 49\%) qualify for amounts that lead to gains of more than this. The share of those aged over 64 who experience a very large increase in their incomes (over 60\%) is considerably higher in the UK than in Denmark $13 \%$ compared with $3 \%$.

Although the cost of this reform scenario is of a comparable relative magnitude in Italy and Denmark, in Italy the beneficiaries of the reform among those aged over 64 are in the minority with $37 \%$ gaining between $10 \%$ and $60 \%$ of their income (with few gaining more than this) and $4 \%$ less than $10 \%$. In Denmark more people gain smaller amounts (34\% benefit by less than $10 \%$ ) and a small minority (3\%) gain very large amounts. The German beneficiaries are divided quite evenly between those gaining a lot and those gaining relatively little. Germany has the highest proportion of those who gain more than $60 \%$ (18\%). 
Figure 1. Increases in household disposable income of people aged 65+ due to a minimum pension of $40 \%$ of average earnings

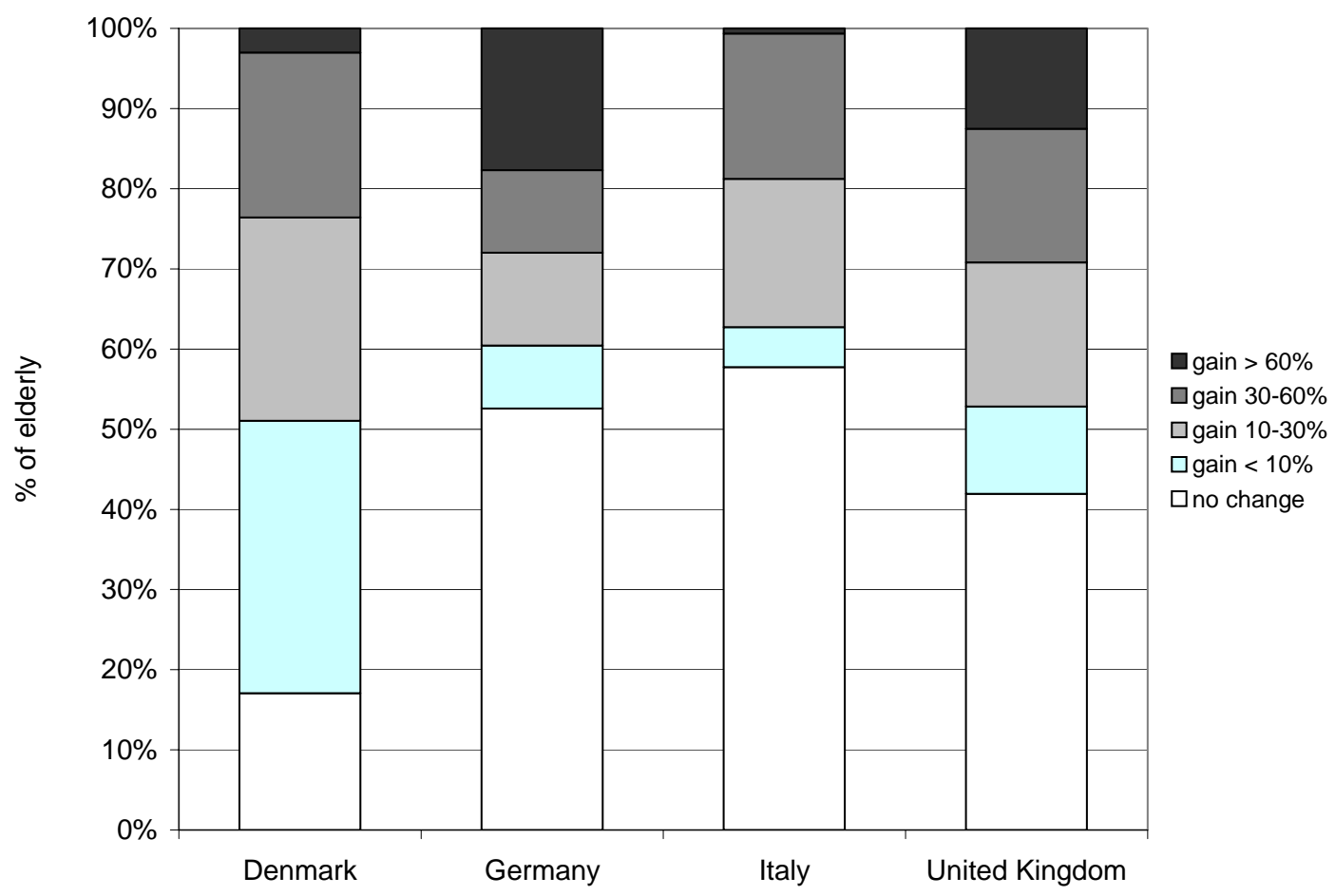

Source: EUROMOD

Figure 2 shows the average proportional gain in disposable income among all households across the income distribution. The distributional effect is partly as a consequence of the position in the income distribution of pension recipients. Appendix 3 shows the position of pensioners (people in receipt of a pension, regardless of age) and people aged 65+ (whether or not they receive a pension). In Denmark pensioners are concentrated at the bottom of the income distribution: the concentration of gains from the minimum pension at these levels of income shown in Figure 2 is therefore not surprising. In the other three countries pensioners are spread more evenly by income level: UK pensioners are to be found disproportionately in the lower-middle parts of distribution (deciles 3 and 4) and the number of Italian pensioners in the bottom decile group is disproportionately small. ${ }^{13}$

However, the average gains for households located close to the bottom of the income distribution are even larger in relative terms in Germany than in Denmark. This may be an indication that even though many Danish pensioners are concentrated at the bottom decile, their pensions are not extremely low, at least in comparison with their German counterparts at this position in the income distribution. The picture in Italy is less pro-poor since the beneficiaries of the reform are more evenly spread across the income distribution, in comparison with the other three countries.

13 The position of the elderly is similar to that of pensioners although, with the exception of Denmark, there is a tendency for the elderly to be more concentrated at lower income levels than those with pension income. This effect is not observed for Denmark because many of the 65-66 group (non pensioner elderly) are still economically active. 
Figure 2. Proportional changes in income by decile due to a minimum pension equal to $40 \%$ of average earnings

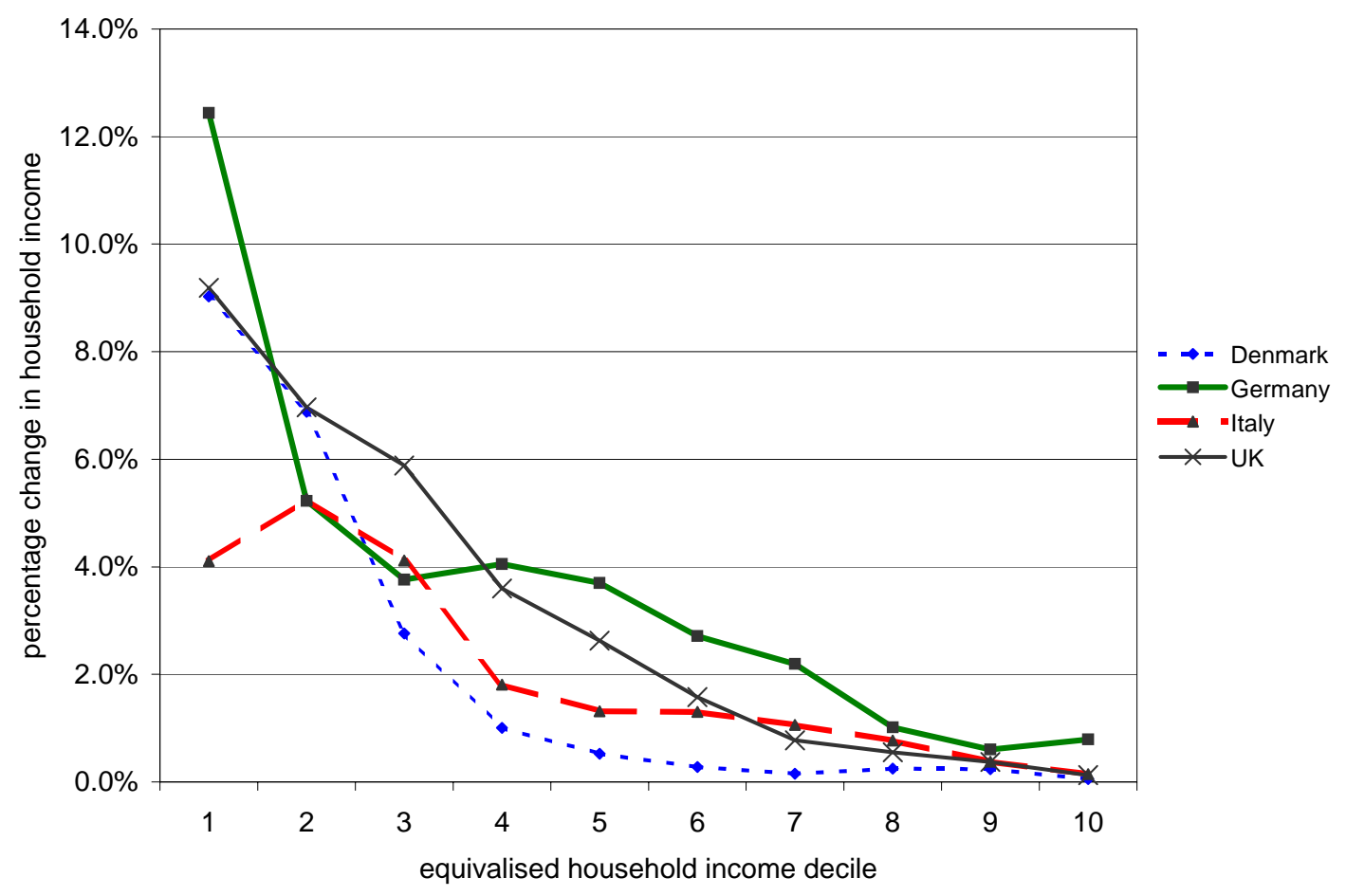

Source: EUROMOD

In order to explore further the relationship between cost and effectiveness in poverty reduction among pensioners, other levels of minimum pension are also simulated. Table 5 shows the level in terms of proportions of average earnings (20\%, 30\%, $40 \%$ and $50 \%)$ in euro per year, not adjusted for purchasing power, our measure of net cost that can be compared across country (percentage increase in household disposable income) and the proportion of elderly people in households which gain. The effect of a low level of minimum pension (20\% of average earnings) is very small in Italy and Denmark. Existing minimum pensions are higher in value than this minimum (see Table 2) and the only beneficiaries are those not eligible for these existing minima (but in receipt of pension income). There is a more substantial effect in Germany and the UK: $14 \%$ and 13\% respectively of elderly are beneficiaries. Generally the relationship between the level of the minimum and its cost is very similar in Denmark and Italy: the cost is relatively low at low levels of the minimum because few people qualify for small amounts.

In the Danish case large numbers of pensioners become entitled to relatively small amounts as the level of the minimum rises. Proportionately fewer pensioners benefit in Italy, but those who do, on average, gain more. In Germany, implementation of the minimum pension is more costly than in the other countries at all levels of the minimum; the cost rises in line with the level of the minimum, due to the (mainly) proportional nature of German contributory pensions. In the UK the numbers entitled rise steeply between the $20 \%$ and $30 \%$ levels due to the concentration of pensioners on similar levels of income. This is rather like in Denmark, but in the UK case the numbers entitled at high levels of the minimum are not so large, due to more widespread and developed private occupational pensions. Thus at high 
levels of the minimum the proportions entitled are more like the proportions in Germany, but the cost is lower.

Table 5. Effects of a minimum pension scheme, by level of the minimum

\begin{tabular}{crrrr}
\hline \% of average earnings: & $\mathbf{2 0 \%}$ & $\mathbf{3 0 \%}$ & $\mathbf{4 0 \%}$ & $\mathbf{5 0 \%}$ \\
\hline $\begin{array}{c}\text { Minimum pension level €/year } \\
\text { Denmark }\end{array}$ & 6,604 & 9,906 & 13,208 & 16,511 \\
Germany & 5,834 & 8,751 & 11,668 & 14,586 \\
Italy & 3,528 & 5,292 & 7,056 & 8,820 \\
UK & 5,337 & 8,006 & 10,675 & 13,344 \\
\hline \% increase in household disposable income & & & \\
Denmark & 0.02 & 0.35 & 1.40 & 2.98 \\
Germany & 0.45 & 1.30 & 2.87 & 5.24 \\
Italy & 0.06 & 0.31 & 1.38 & 2.36 \\
UK & 0.08 & 0.82 & 2.16 & 3.94 \\
\hline \% of people aged 65+ that gain & & & & \\
Denmark & 3.7 & 49.2 & 82.9 & 84.9 \\
Germany & 14.3 & 30.2 & 47.4 & 66.3 \\
Italy & 1.5 & 31.4 & 42.3 & 47.7 \\
UK & 12.7 & 43.3 & 58.0 & 63.9 \\
\hline
\end{tabular}

Source: EUROMOD

Table 6 provides detailed estimates of the effects of the minimum pension on elderly poverty. Clearly, in all countries the larger the minimum pension the larger the reduction in the elderly poverty rate. However, the relationships are not equally strong in all countries. In Denmark the minimum pension is very effective at reducing elderly poverty from its high starting rate. At the $40 \%$ level nearly all elderly people who could benefit are in receipt and two thirds of those below the poverty line before the reform are now above it. But due to the relatively high level of the Danish poverty line, it takes a minimum pension of $50 \%$ of earnings to raise (nearly all) the final third above the poverty line.

In Italy only higher levels of minimum pension are effective at reducing elderly poverty. There are two reasons for this. First, a relatively low proportion of Italian elderly qualify, leaving $8 \%$ below the poverty line even when the minimum pension is at the highest level considered. Secondly, it is only at $40 \%$ of earnings that the minimum pension is above the Italian poverty line. In Germany and the UK the minimum pension level is above the poverty line (for a single person) at the $30 \%$ level. In Germany the returns, in terms of poverty rate reduction, are greater for higher levels of minimum pension up to the $40 \%$ level. There is little improvement in poverty rate from increasing the level of the minimum pension to $50 \%$, even though the proportion gaining continues to rise. Similar "diminishing returns" set in for the poverty rate in the UK at 50\%, and the numbers benefiting level off too. 
Table 6. Effects of the introduction of minimum pension on poverty among the elderly

\begin{tabular}{lrcccc}
\hline Index & Scenario & Denmark & Germany & Italy & UK \\
\hline Poverty rate (65+) & baseline & 31.0 & 13.9 & 18.0 & 22.6 \\
& $20 \%$ & 31.0 & 12.9 & 17.9 & 22.1 \\
& $30 \%$ & 23.1 & 9.6 & 16.9 & 14.6 \\
& $40 \%$ & 11.4 & 4.3 & 8.2 & 1.4 \\
\hline FGT (a=2) (65+) & baseline & 0.483 & 0.978 & 1.189 & 0.730 \\
& $20 \%$ & 0.481 & 0.656 & 1.181 & 0.675 \\
& $30 \%$ & 0.324 & 0.369 & 1.003 & 0.125 \\
& $40 \%$ & 0.177 & 0.344 & 0.624 & 0.065 \\
& $50 \%$ & 0.121 & 0.334 & 0.491 & 0.062 \\
\hline
\end{tabular}

Source: EUROMOD

Minimum pensions, especially when set at levels equal to, or higher than, $40 \%$ of average earnings, appear to reduce the elderly poverty rate substantially, particularly in Denmark and the UK. On the other hand the intensity of poverty using FGT(a=2) is reduced significantly in Germany with quite low levels of minimum (at $20 \%$ of average earnings it is reduced by nearly one third). Figure 3 shows the returns to higher levels of minimum pension generosity in terms of reductions in poverty among the elderly as measured by the FGT $(\mathrm{a}=2)$; that is, taking into account the impact of the simulated minimum pension schemes on the intensity, as well as extent of poverty among the elderly. This clearly shows that in Germany and the UK there are levels of minimum pension above which there is rather little improvement. For Germany this corresponds to a minimum pension of about $30 \%$ of average earnings and it appears that this policy cannot reduce poverty as measured by FGT(a=2) to less than about a third of its baseline level. This residual must be explained by elderly not covered by pension entitlements and hence, not entitled to the minimum. Table 6 shows that higher levels of minimum pension do result in reduced poverty rates, indicating that a minimum pension of around $40 \%$ is needed to raise some remaining pensioners from just below to just above the poverty line. A similar picture is apparent in the UK, although a higher level of minimum (40\%) is necessary to secure large reductions in poverty intensity. Poverty is then almost eradicated, indicating that while the level of existing pension is low for many UK elderly, coverage is relatively comprehensive.

The small residual poverty rate in Denmark at the $50 \%$ level of minimum pension corresponds to the low income elderly aged 65-66 who were not qualifying for pension in 1998. The value of the FGT $(a=2)$ remains at $25 \%$ of its baseline level, even with the high minimum pension in place is a result of, on the one hand, the low level of baseline intensity of poverty in Denmark and, on the other, the fact that those not qualifying for pension due to being aged under 67 may include a minority with very low incomes.

Figure 3 also shows how, in all four countries, the fiscal cost of the introduction of minimum pensions appears to rise at an increasing rate with the generosity of the minimum pension. The following two sections consider two mechanisms by which this may be financed; the first by increasing the fiscal burden on those currently working, and the second by redistributing incomes within the pensioner populations. 
Figure 3. Reduction in poverty among the elderly by levels of generosity of the minimum pension

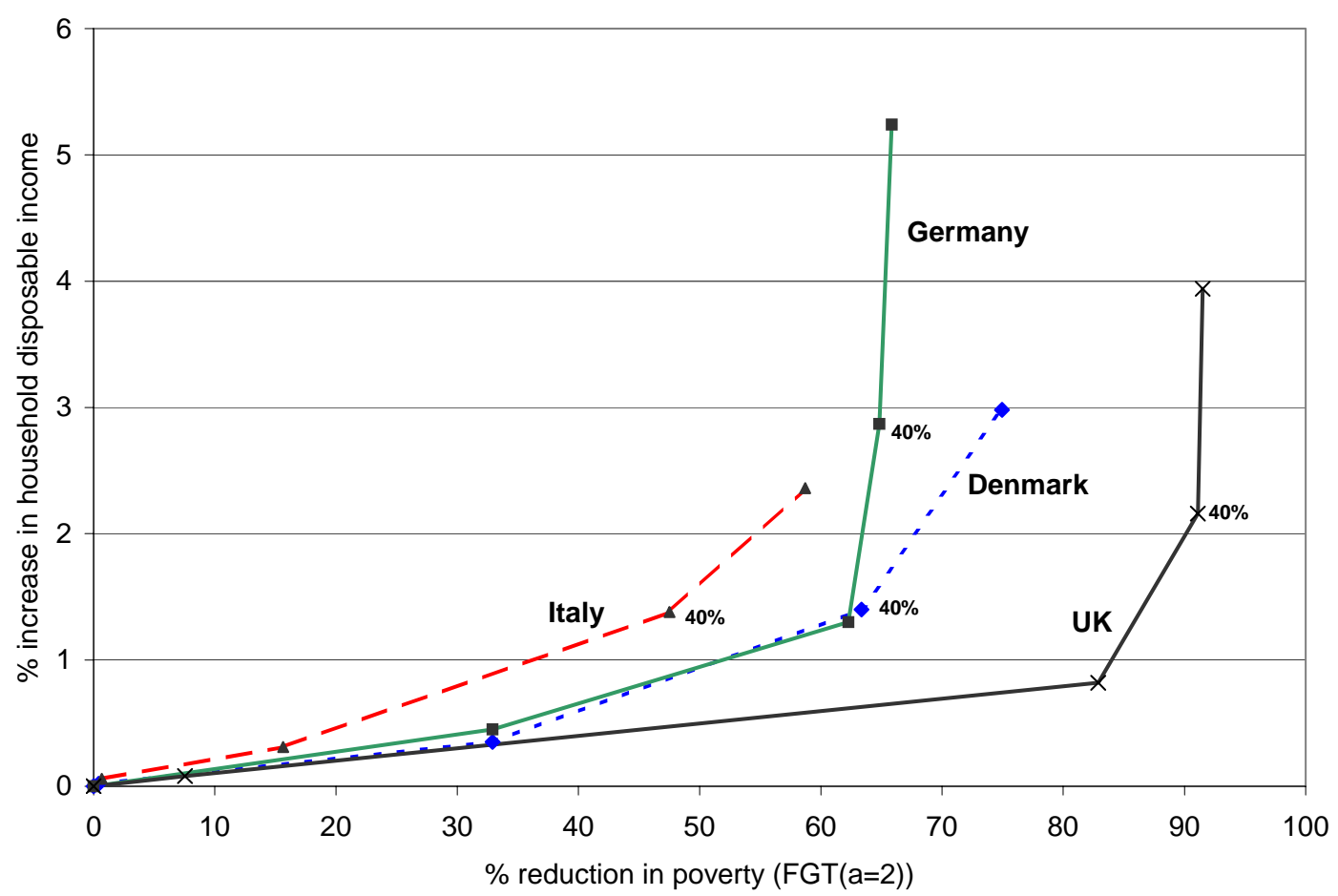

Source: EUROMOD

Note: Successive points on each line indicate minimum pension levels equal to $20 \%, 30 \%, 40 \%$ and $50 \%$ of average earnings, respectively.

\subsection{Reform 2: increasing contributions}

We explore the impact of increasing contribution rates on the amount of revenue raised and on poverty by simulating increases of 1,2 and 3 percentage points in all rates of pension contribution. In Germany this is straightforwardly done: in first case the employee's rate is increased from $10.15 \%$ to $11.15 \%$ in both East and West Germany. In Denmark the rate of tax that finances the old age pension is increased from $8 \%$ to $9 \%$. In the UK each of the Class 1 rates of contribution (for those contracted out and not contracted out of the state earnings related pension) are increased by 1 percentage point (from $8.4 \%$ to $9.4 \%$ and from $10 \%$ to $11 \%$ respectively); the rate on earnings below the lower threshold in 1998 is also increased (from 2\% to 3\%); and the rate on self-employed profits is increased from $6 \%$ to $7 \%$. In Italy there are many rates for people in different forms of employment and selfemployment: these are all increased by 1 percentage point. We also take account of the fact that as well as contributions paid on a proportional basis (within limits) in some contributory systems there also are fixed or flat contributions. In these cases we increase the flat payment in proportion to the change effected in the main simulation. Such increases also apply in Denmark and the UK.

Table 7 shows the aggregate effect of the three levels of increase in contribution rates, in terms of the proportional change in household disposable income. Within countries, larger increases in marginal rates result in aggregate effects that are proportionately larger. The 
effects differ across countries with the net effect of a 1 percentage point increase in contribution varying from a $1.2 \%$ drop in income in Denmark to $0.5 \%$ in Italy. ${ }^{14}$

Table 7. Aggregate effects of increased contribution rates

\begin{tabular}{lccccc}
\hline Index & Scenario & Denmark & Germany & Italy & UK \\
\hline \% change in & SIC $+1 \%$ & -1.22 & -0.73 & -0.47 & -0.59 \\
household & SIC +2\% & -2.44 & -1.45 & -0.94 & -1.17 \\
disposable income & SIC +3\% & -3.67 & -2.18 & -1.40 & -1.76 \\
\hline
\end{tabular}

Source: EUROMOD

This can be explained by cross-country differences in the structure of the systems of pension contribution: a common percentage point increase in rate is of differing significance across systems. In Germany a one percentage point increase in pension contribution represents a relatively small proportional increase in contribution income as a whole (4.4\%) as there are other parallel systems of contribution for other purposes (unemployment etc). In Italy the proportional increase in contribution income is twice as high as in Germany (8.8\%), reflecting the greater relative importance of pensions in the contributory system and employee contribution rates that are on average lower than in Germany (8-9\% in the most common scheme). The proportional increase is larger in the UK (10.7\%) because the starting average rate is relatively low. In Denmark most of the pension system is financed by part of the income tax system. A one percentage point increase in contributions represents a 35 percent proportional increase in existing contributions, due to the very small starting rate.

The effects of the increase in contributions according to position in the distribution of household income are shown in Figure 4. Since, as shown in Table 7, the aggregate effect of the change is not equivalent across countries, the proportional change in income is shown as the ratio of the change in each decile group to that of the population as a whole. This normalisation allows us to focus on differences in distributional effects, rather than differences in the overall size of the impact across countries.

These effects are quite similar in Germany and the UK with the proportional reduction in household income increasing fairly steeply with income up to the top one (UK) or two (Germany) decile groups. Ceilings on contributions in both systems make the contribution system regressive at higher income levels. This, combined with tax relief on contributions in Germany, and the fact that some high earning Germans opt out of the system altogether, make the proportional reduction in income less for the top $10 \%$ than for the rest of the top $50 \%$ (Germany) or $40 \%$ (UK).

The Danish system is only slightly regressive at the very top, but less progressive over the bottom half of the distribution than the German or UK systems. The Italian system is much less differentiated by income level, although this may have as much to do with household composition effects as with the contribution burden by levels of gross earnings. ${ }^{15}$

14 The effect is net of small changes in current benefit expenditure in all four countries (because some income tested benefits are based on income after contributions) and in income tax (except in the UK where contributions are not tax deductible).

15 The net effect of increasing contributions is the average of the effects for each individual within the household. 
In common with Germany and the UK the proportional effect is less in the top decile group in Italy than in the rest of the top half of the distribution.

Figure 4. Proportional reduction in income by decile group relative to the mean following an increase in social insurance contribution rates by one percentage point

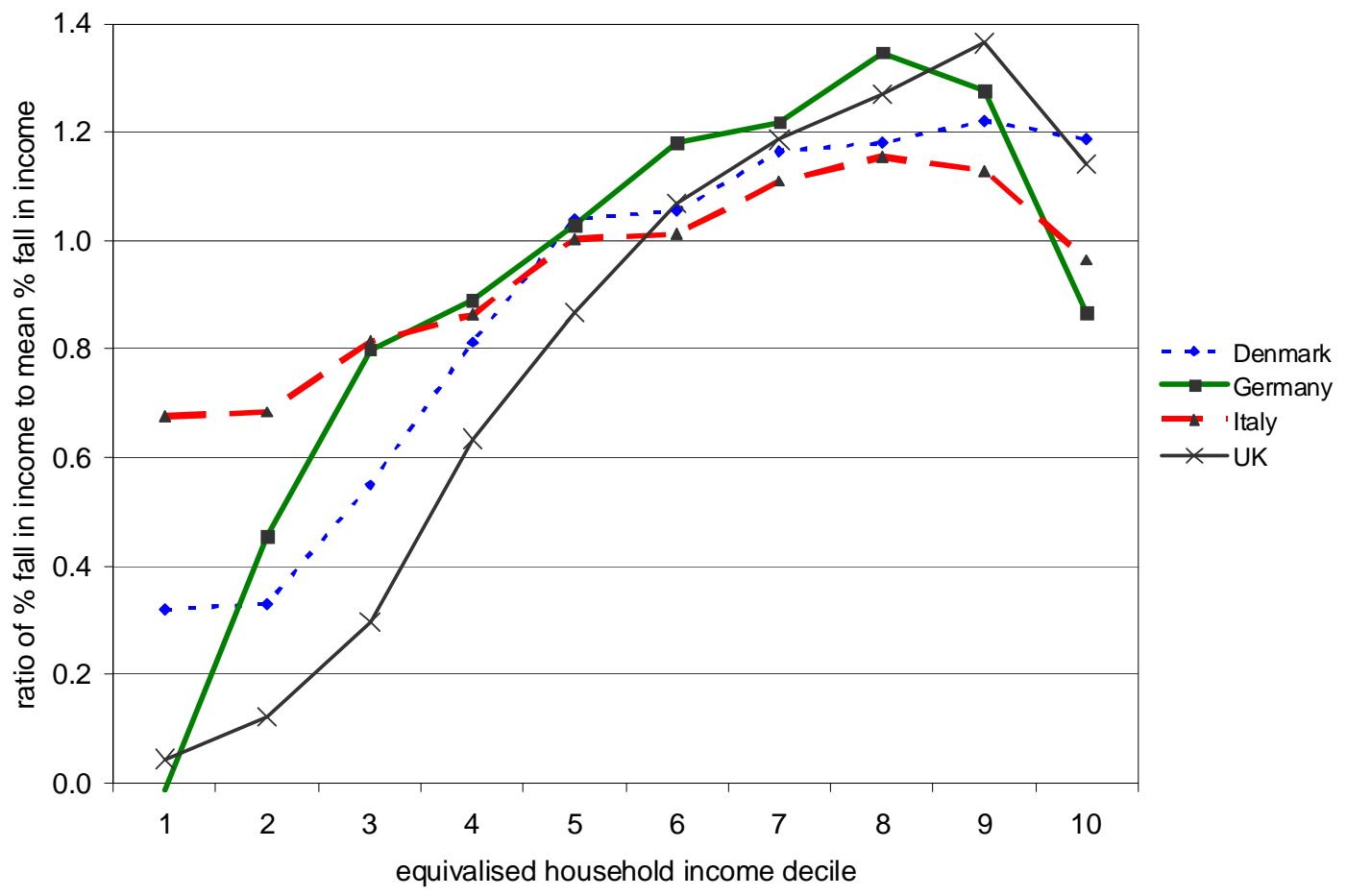

Source: EUROMOD

Note that for each decile group the proportional reduction in income is shown as the ratio to the mean proportional reduction

Given that the increases in contribution rates affect almost exclusively the non-elderly, they are likely to leave the poverty situation of the elderly largely unchanged since in our analysis the poverty line is kept fixed. At the same time, to the extent that at least some contributors are in households near or below the poverty line, it might be expected that increasing contributions might exacerbate poverty in general. Table 8 shows the percentage point increase in poverty rates for the national populations following each of the three increases in contribution rate. While the effects are generally small, they are largest in Italy, where (as shown in Table 2, above) nearly all employed persons pay pension contributions. Only $2 \%$ of Italian employees in the bottom quintile group by disposable income pay no contribution. In Germany and the UK low earnings are exempt from contributions: $29 \%$ and $39 \%$ respectively of employees in the bottom quintile group pay no contributions.

We can conclude that raising revenue to finance pensions through higher contributions is most problematic from a distributional point of view in the Italian system. Italian contributors are more likely to have low incomes and a significant share of the extra burden is borne by them. 
Table 8. Effects on poverty rates of increasing contribution rates

\begin{tabular}{lccccc}
\hline Index & Scenario & Denmark & Germany & Italy & UK \\
\hline Poverty rate (all) & baseline & 11.4 & 9.9 & 20.1 & 19.9 \\
Increase in poverty rate (percentage points) & & & \\
& SIC +1\% & 0.16 & 0.04 & 0.23 & 0.03 \\
& SIC +2\% & 0.24 & 0.22 & 0.45 & 0.12 \\
SIC +3\% & 0.32 & 0.32 & 0.61 & 0.22 \\
\hline
\end{tabular}

Source: EUROMOD

\subsection{Reform 3: Reducing the replacement rate in contributory pensions in payment}

This reform scenario focuses exclusively on the incomes of the pensioners. The purpose is to gauge the size of savings and the distributional effects on the elderly of a proportional reduction of pensions in payment (by 5\%, 7\% and 10\%). Although in a shortterm framework it is very unlikely that pensions can be cut in real terms like this - unless there is a severe financial crisis - the common practice of many governments has been to let the pensions lag behind incomes from other sources by linking pensions to the Retail Price Index rather than average earnings. ${ }^{16}$ In this scenario we reduce the earnings-related and flat rate contributory components of state pension systems. The main flat rate components are the basic pension in the UK and the old age citizens pension in Denmark. These are nearuniversal in coverage although the Danish scheme, operating from the age of 67 in 1998, excludes some $12 \%$ of the elderly because they were aged 65 and 66 . The state earnings related schemes cover $90 \%$ of those aged over 64 in Germany and $87 \%$ in Italy. Table 9 shows the aggregate effects of a $5 \%$ cut.

Table 9. Effects of decreasing contributory state pension payments (by $\mathbf{5 \%}$ )

\begin{tabular}{lcccc}
\hline \% change & Denmark & Germany & Italy & UK \\
\hline Household disposable income & -0.27 & -0.92 & -0.79 & -0.23 \\
Benefits and state pensions & -1.44 & -3.25 & -3.78 & -1.24 \\
Social contributions & 0.00 & -0.40 & 0.00 & 0.00 \\
Taxes & -0.34 & -0.27 & -1.52 & -0.18 \\
\hline
\end{tabular}

Source: EUROMOD

The importance of the earnings related components, and in particular the lack of a ceiling on payments (see Table 2) in Germany and Italy is shown by the large aggregate reduction in benefits as a whole - more than 3\% in both countries. The effect is mitigated by the income tax system, to a greater extent in Italy than Germany. In the former case, pensions

16 Our illustrative reduction in pension payments is also indicative of the effects of other short-to-mediumterm strategies for reducing pension spending available to, or practised by, governments. Replacement rates can be reduced explicitly (e.g. as proposed in Germany) or implicitly (by changing the definition of reference earnings). 
are taxed as earnings, whereas in Germany they are taxed much less heavily. ${ }^{17}$ On the other hand, in Germany pension income itself attracts contributions, which fall along with pension income.

In the UK and Denmark state pensions make up a relatively small component of total benefit expenditure. While pensions are lowered by $5 \%$ this represents only a $1.2 \%$ and $1.4 \%$ decrease in total benefits respectively in the two countries. In the UK this is partly because the fall in contributory state pension is compensated by an increase in social assistance or housing benefits for many low income pensioners. Increases in these benefits make up for about $30 \%$ of the fall in contributory pension. There is a similar effect in the other three countries but it is much smaller: 4\% in Denmark and Germany and 3\% in Italy.

Figure 5 shows the distributional effects in terms of the proportional reduction in disposable income across the household income distribution. In Denmark the concentration of losses from the pension reduction at low levels of income corresponds with the location of pensioners at the bottom of the income distribution (see Appendix 3).

Figure 5. Proportional changes in income by decile following a proportional decrease in contributory pension payments by $5 \%$

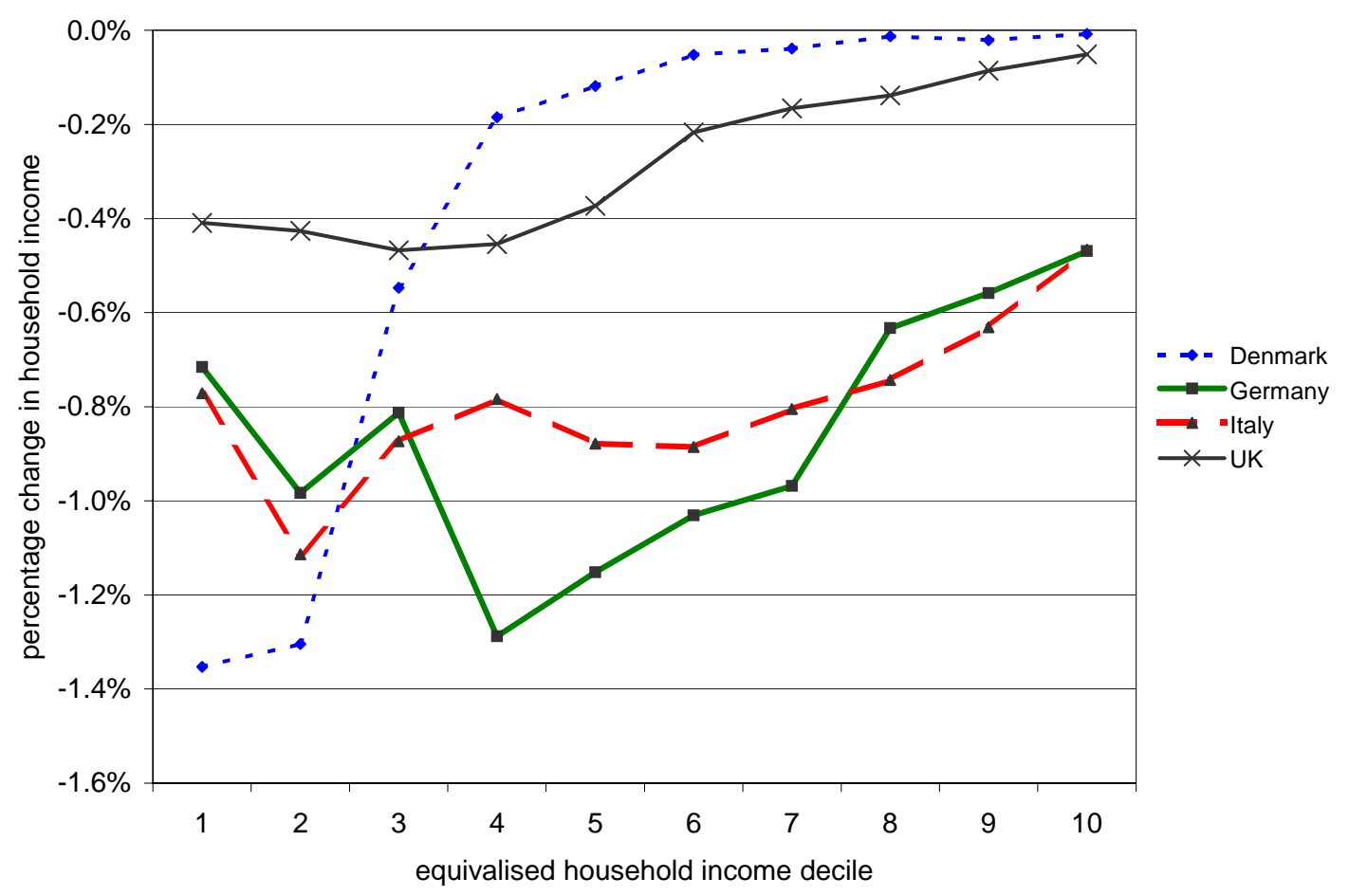

Source: EUROMOD

In the UK, the rather flat distributional effect is due to the compensation of low income pensioners by an increase in social assistance benefits. Another feature is the low level of UK state pensions in relation to other incomes: a proportional reduction is smaller in

17 See Keenay and Whitehouse (2003) for a cross-country comparison of the taxation of incomes in retirement. 
absolute size than the same reduction in Italy or Germany. However, it is clear that in all four countries a cut in the state contributory pension is a regressive measure due to the position of pensioners in the income distribution as a whole: proportional reductions in pensions affect disproportionately the lower decile groups.

Table 10 reports the effects on poverty among the elderly of the proportional cuts in pensions. The poverty rate rises in all countries - most in Denmark and, to a lesser extent, Germany. Apparently, in these countries a considerable proportion of the elderly are located just above the poverty line. Poverty intensity increases too: many of the elderly who are below the poverty line and are not eligible for social assistance face a decline in their social transfers. Hence, the increase in the FGT(a=2). In fact, after the pension cuts, in all countries apart from Germany the proportional increases of the FGT(a=2) are larger than those of the poverty rate.

While the revenues (as measured by the proportional reduction in disposable incomes) resulting from the cuts are quite small in the case of Denmark, the impact on the poverty measures is the largest, at each level of the cut. The proportional income reductions are larger for Germany and Italy, and the impact on poverty indictors is less, reflecting the earningsrelated nature of their pension systems. In the UK both the aggregate income and the poverty effects are dampened by the role of income-tested benefits. It seems there is most scope for redistribution among pensioners in Germany and Italy but very little in Denmark.

Table 10. Poverty and aggregate income effects of proportional reductions in pensions

\begin{tabular}{lrcccc}
\hline Index & Scenario & Denmark & Germany & Italy & UK \\
\hline Poverty rate (65+) & baseline & 31.0 & 13.9 & 18.0 & 22.6 \\
& $-5 \%$ & 36.8 & 16.7 & 18.9 & 23.8 \\
& $-7 \%$ & 39.2 & 17.0 & 19.7 & 24.6 \\
& $-10 \%$ & 42.2 & 18.6 & 20.7 & 25.4 \\
\hline FGT (a=2) (65+) & baseline & 0.483 & 0.978 & 1.189 & 0.730 \\
& $-5 \%$ & 0.653 & 1.065 & 1.334 & 0.855 \\
& $-7 \%$ & 0.739 & 1.107 & 1.396 & 0.906 \\
\hline \% change in total & $-10 \%$ & 0.894 & 1.186 & 1.491 & 0.985 \\
disposable income & $-5 \%$ & $-0.27 \%$ & $-0.92 \%$ & $-0.79 \%$ & $-0.23 \%$ \\
& $-10 \%$ & $-0.38 \%$ & $-1.28 \%$ & $-1.11 \%$ & $-0.32 \%$ \\
\hline
\end{tabular}

Source: EUROMOD

\section{$5 \quad$ Reform packages}

We can combine the three elements of reform into revenue-neutral packages. Examination of the individual components above has shown that some types of reform are more cost-effective in some countries than in others. There are many dimensions to consider and in this first attempt we select, at the national level, combinations of components that maximise the reduction in the elderly poverty rate while being mindful of the tax burden of the working age population. Focus on alternatives such as the FGT(a=2) indicator for the elderly, gender-specific poverty indicators, poverty indicators for the whole population or on 
the relative incomes of elderly and non-elderly (or many other important outcomes) might lead us in different directions. The main purpose at this stage it to demonstrate the existence of a range of options and of the need to take national circumstance into account. The packages we consider all involve a minimum pension set at $40 \%$ of average earnings, together with:

Denmark: Percentage point increase in pension contributions (and earmarked taxes): 1.2 Change to existing pensions: none

The rationale for the Danish package is that there is little point in reducing existing pensions if they are not earnings related. The cost of the $40 \%$ minimum is borne by a large increase in taxes/contributions paid by people in employment.

Germany: Percentage point increase in pension contributions: 3.0

Change to existing pensions: $5 \%$ reduction

Italy: $\quad$ Change in pension contributions: None

Change to existing pensions: $11 \%$ reduction

We have seen that increasing Italian contributions has some impact on poverty. There is already significant income inequality among pensioners. So the package involves redistribution within pensioner incomes - a large proportional cut in existing pensions.

UK: $\quad$ Percentage point increase in pension contributions: 3.3

Change to existing pensions: $10 \%$ reduction

The UK package combines all elements. Both the cut in state pensions and the increase in contribution rate are relatively large because in each case the base is relatively small. The distributional effects of the four packages are shown in Table 11.

Table 11. Distributional effects of the reform packages

\begin{tabular}{lrcccc}
\hline Index & Scenario & Denmark & Germany & Italy & UK \\
\hline Income ratio & baseline & 0.67 & 0.92 & 1.00 & 0.81 \\
& reform & 0.76 & 1.03 & 1.03 & 0.90 \\
& change & 0.09 & 0.11 & 0.02 & 0.09 \\
\hline Poverty rate (all) & baseline & 11.4 & 9.9 & 20.1 & 19.9 \\
& reform & 8.8 & 8.6 & 18.5 & 16.8 \\
& change & -2.6 & -1.3 & -1.7 & -3.1 \\
\hline Poverty rate (65+) & baseline & 31.0 & 13.9 & 18.0 & 22.6 \\
& reform & 11.4 & 4.8 & 8.6 & 1.5 \\
& change & -19.6 & -9.1 & -9.4 & -21.1 \\
\hline FGT (a=2) (all) & baseline & 0.973 & 0.673 & 3.131 & 1.107 \\
& reform & 0.941 & 0.565 & 3.006 & 1.012 \\
& change & -0.032 & -0.108 & -0.125 & -0.095 \\
\hline FGT (a=2) (65+) & baseline & 0.483 & 0.978 & 1.189 & 0.730 \\
& reform & 0.178 & 0.345 & 0.658 & 0.070 \\
& change & -0.305 & -0.633 & -0.531 & -0.660 \\
\hline Gini coefficient & baseline & 0.207 & 0.340 & 0.439 & 0.330 \\
& reform & 0.160 & 0.230 & 0.396 & 0.290 \\
& change & -0.047 & -0.110 & -0.043 & -0.040 \\
\hline
\end{tabular}

Source: EUROMOD 
First, and not surprisingly, the ratio of household income of the elderly rises when compared with incomes of other people. This effect is smallest in Italy (the effect is only due to the way redistribution occurs across households containing elderly people). The effect is particularly large in Germany, in spite of the large cut in earnings related pensions. Poverty among the elderly falls considerably in all countries and the net effect of the packages on poverty in general is to clearly reduce it. The progressive effect across the distribution of all household incomes is illustrated in Figure 5. In UK and Germany decile groups 1 to 5 are all net gainers. In Denmark this is the case for decile groups 1 to 3, and for Italy groups 1 to 4 .

\section{Figure 5. Proportional changes in household income by decile due to reform packages}

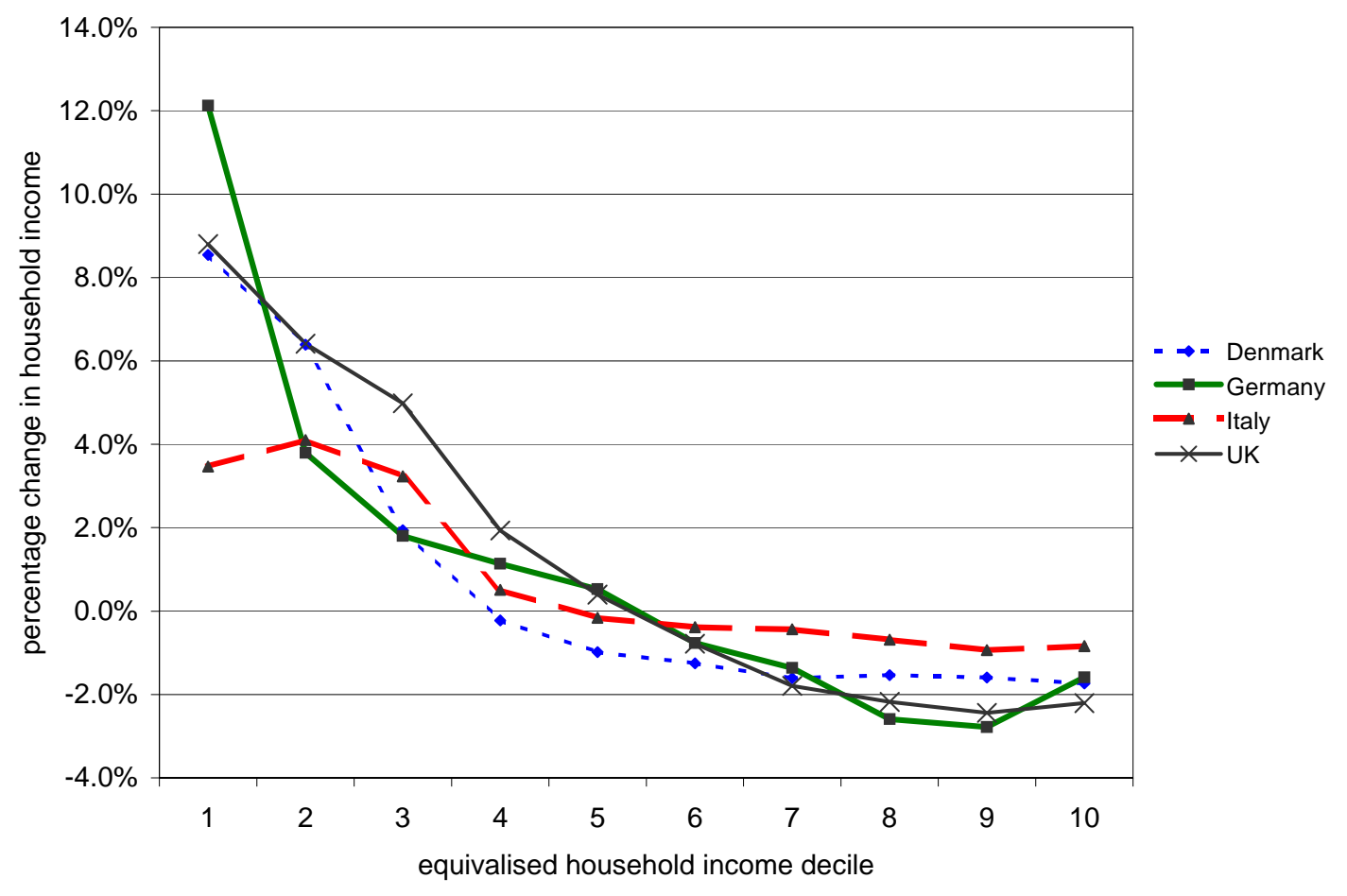

Source: EUROMOD

Another way to look at the distributional impact of the simulated changes but focusing exclusively on the elderly is through the examination of the frequency distributions of their incomes before and after the reforms. The evidence is reported in Figure 6. Naturally, in all countries the distribution shifts to the right, fewer elderly persons are left below the poverty line and in all countries (with the partial exception of Italy) a considerable proportion of the elderly are concentrated around the new minimum pension. However, cross-country differences are striking. In Denmark, which has the most concentrated income distribution among the elderly, after the reform a twin-peak distribution emerges. The elderly making up the left peak are persons aged over 64 but below state retirement age (67). The elderly around the right peak are elderly persons who qualify for the new minimum pension simulated in our reform, which is more generous than the minimum pension of the baseline scenario. Italy has the least concentrated income distribution of the elderly among the countries examined here; a feature hardly affected after the simulation of our reforms. Compared with the other three 
Figure 6. Distribution of the elderly by level of household income before and after the reform packages

Denmark

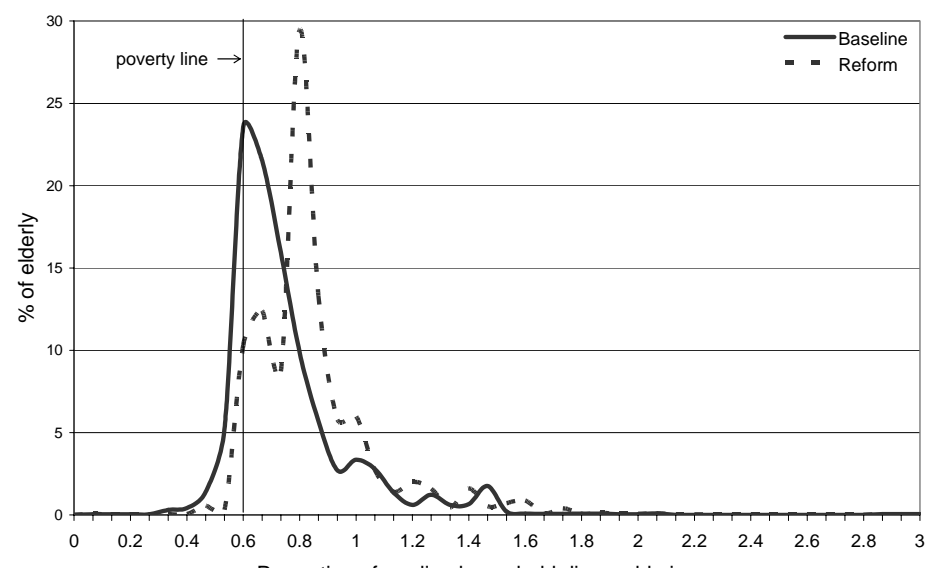

Italy

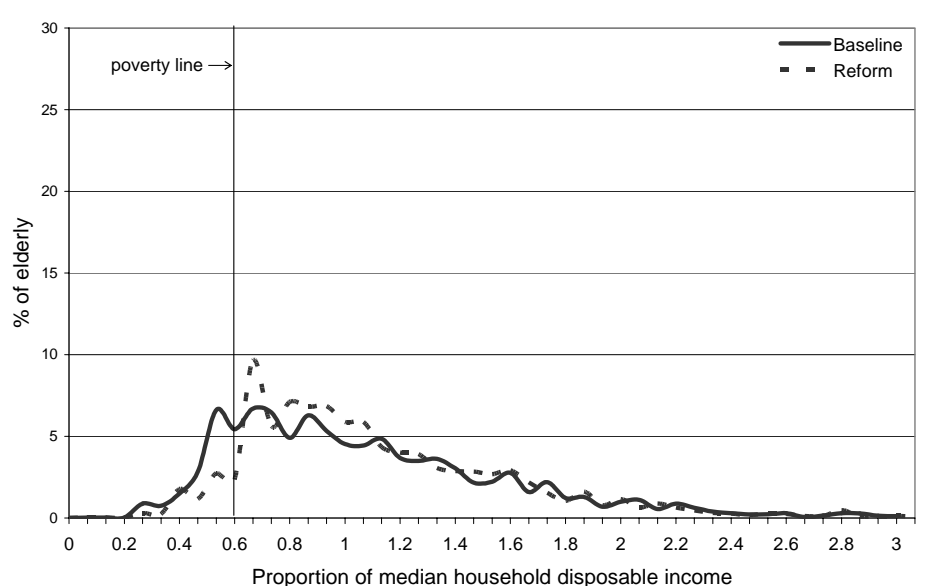

Germany

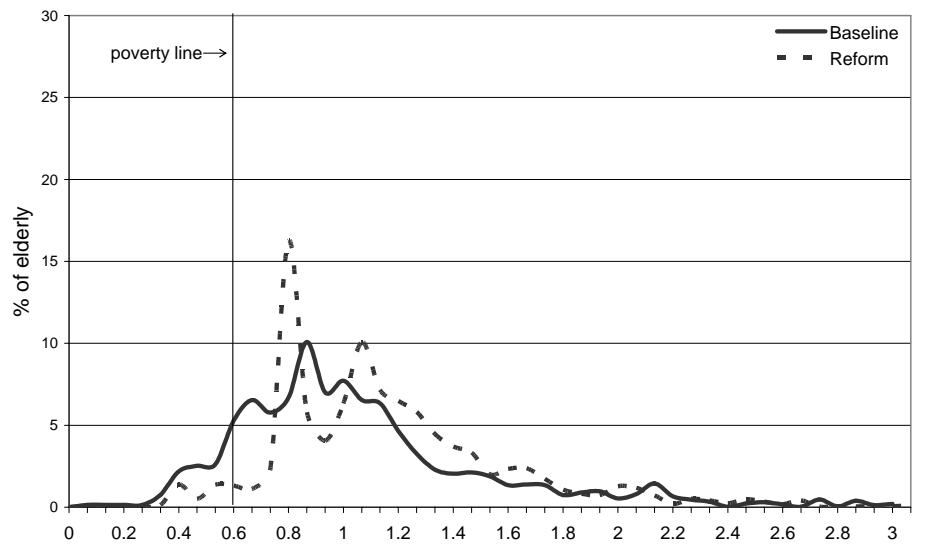

Proportion of median household disposable income

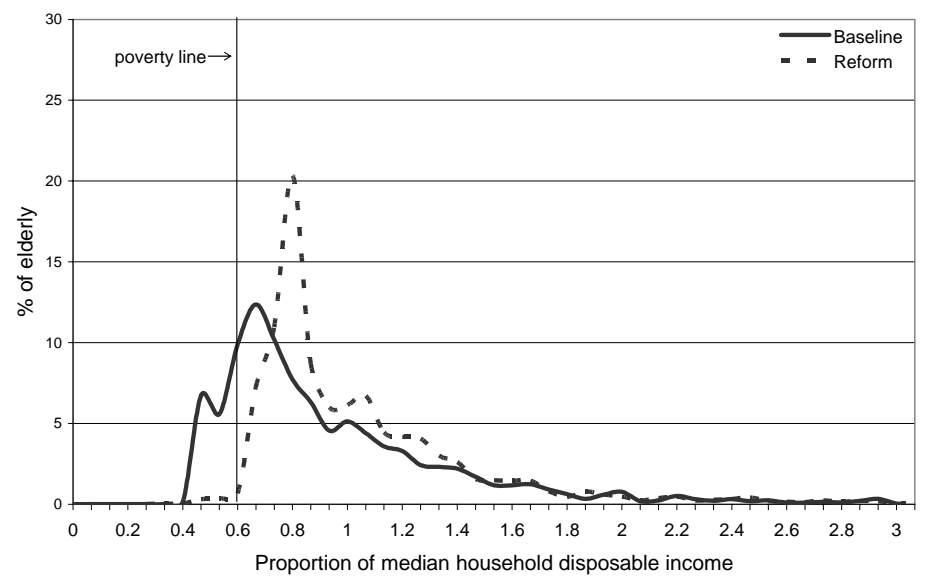

Source: EUROMOD. Note that incomes are measured in relation to the pre-reform median. The upper tails of the distributions have been truncated at 3 times median income. The proportions of the elderly not shown in each country are 0.05\% (Denmark), 0.39\% (Germany), 3.98\% (Italy) and 1.45\% (UK). 
countries considered a relatively large number of the Italian elderly do not qualify for a pension, and at the same time a relatively high proportion share households with non-elderly see below for indirect evidence - the effect of the simulated reform in Italy is not as effective in reducing elderly poverty as in the other countries. In the UK the frequency distribution of the elderly has two peaks in the baseline scenario. In fact, the first of these peaks lies below the poverty line. After the reform, poverty in Britain is almost eradicated with a single peak above the poverty line, indicating the high proportion of British concentrated around the level of the simulated minimum pension. Perhaps the most interesting post-reform picture emerges in Germany. Few elderly are left below the poverty line after the reform, while the reform produces a twin-peak distribution of the elderly, with both peaks clearly lying to the right of the poverty line. This is due to the fact that many, German low income couples each benefit from the minimum pension - these make up the peak on the right. Couples with one beneficiary and single beneficiaries are concentrated in the lower-income peak.

Figure 7 shows the proportions gaining and losing different amounts, first for the elderly and then, on the right-hand of the chart, for the populations as a whole. Denmark shows large proportions of elderly gaining both large and small amounts, paid for exclusively by relatively small proportional reductions in income among the working age population. In contrast, in the other three countries there are some quite large reductions in income. These are mainly confined to the elderly.

Figure 7. Gainers and losers from pension reform packages

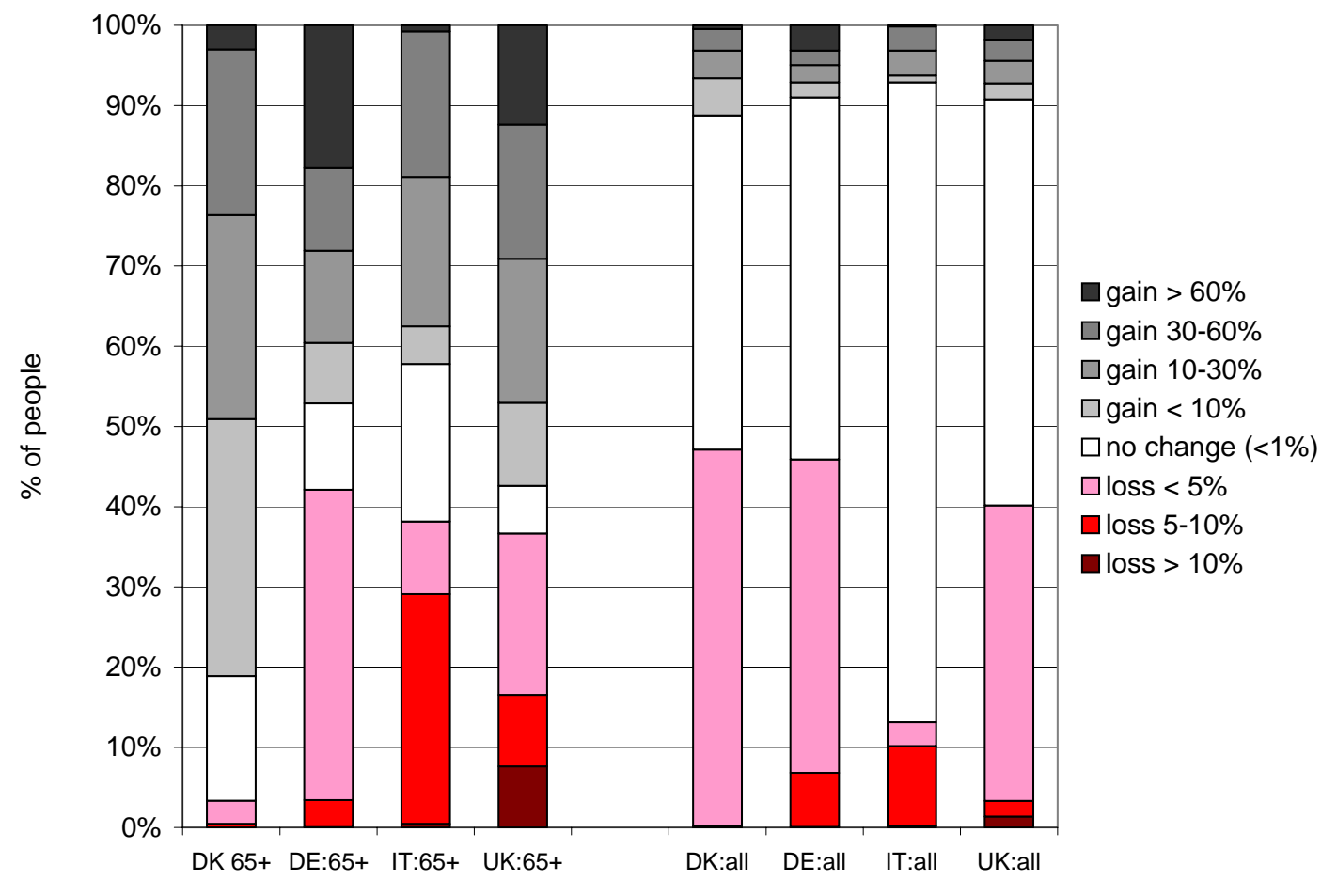

Source: EUROMOD

As shown in Table 11, poverty among the elderly is all but eradicated in the UK. The German poverty rate for the elderly also falls to a very low level, and the FGT(2) indicator declines by around the same proportion. While still substantial, the fall in poverty rate among 
the elderly in Italy is less dramatic than in the other three countries. This is partly because a residual group of Italian low income elderly do not qualify for public pensions and are not affected by the reform package. As shown in Table 2 above the pension coverage rate is lowest in Italy among the four countries considered (81\% compared with 88\%. 90\% and 98\% in Denmark, Germany and UK respectively). This is part of the explanation for the persistence of poverty both in terms of rate and severity in spite of the generous minimum pension. Another part of the explanation may lie in the extra burden of other household members on pension income. Table 12 shows how pension income is the major source of household income for a much larger proportion of younger Italians (aged under 50), than it is for the same age group in other countries.

Table 12: Proportion of people aged under 50 whose household income comprises at least half pension income from an elderly person

\begin{tabular}{lcccc}
\hline$\%$ & Denmark & Germany & Italy & UK \\
\hline All & 0.2 & 1.6 & 8.0 & 1.6 \\
In bottom quintile group & 0.3 & 3.3 & 12.1 & 2.0 \\
\hline
\end{tabular}

Source: EUROMOD

The difference is particularly marked in the bottom quintile groups where $12 \%$ of Italians depend on pension income of elderly persons in the same household, compared with $3 \%$ in Germany and 2\% in the UK. It is simply that larger increases in pension income are needed to push all Italian households containing the elderly across the poverty line. ${ }^{18}$

Finally, we see from the reduction in the Gini coefficient - shown in Table 11 above that the reforms bring about a considerable reduction in inequality among the elderly. Again, this is to be expected and but is especially large in the German case. Figure 5 shows particularly large average gains at the bottom of the German income distribution. About 18\% of German elderly increase their incomes by more than $60 \%$ whereas the corresponding proportions are $12 \%$ in the UK and only $3 \%$ and $1 \%$ in Denmark and Italy respectively.

\section{Conclusions}

We have compared four pension systems and analysed their characteristics by discussing a number of illustrative EUROMOD simulations with the aim of highlighting cross country differences and similarities and suggesting nationally-appropriate directions for reform. In doing so, our approach has been entirely normative and takes little account of political economy considerations or indeed, pragmatic political realities. Reform may be constrained in ways that we have not considered, although the numbers of gainers and losers shown in Figure 7 do indicate something of the relevant "political arithmetic". Whatever reform strategy is adopted in practice may well be sub-optimal in terms of the normative

Taking into account that Italy is one of the very few EU countries where a generalised Minimum Income Guarantee scheme does not exist, it can be argued that it might be preferable to support this segment of the population directly through social assistance policies rather than through generous across-the-board increases in existing minimum pension schemes. 
framework that has been adopted in this paper. While our analysis probably cannot be used as a blueprint for realistic reform proposals, it can inform their development.

As anticipated, simply applying proportional cuts to state contributory pensions is a regressive measure due to the position of pensioners in the income distribution in all four countries: proportional reductions in pensions affect disproportionately the lower deciles of the distribution. However, in quantitative terms, cross-country differences are quite substantial. As a result, additional measures are needed to ensure that reducing the level of pensions does not result in increasing pensioner poverty. So we have placed particular emphasis on the consideration of a minimum pension scheme as a central component of a reform strategy.

The relatively generous level of minimum pension set at $40 \%$ of average earnings makes a big difference to low income pensioners in Germany. Given the relatively high inequality among pensioners in this country, we found that the scheme could - within our normative framework - be financed at least in part by redistribution within the pensioner population. The minimum affects the vast majority of pensioners in Denmark where the numbers just below the poverty line are very large. At the core of the Danish pension system there is a residence-based flat amount which makes the system virtually comprehensive (for those aged 67+) but the pension is set at a low level, just around the poverty line. The minimum pension scheme would bring a great many pensioners above it, reducing the elderly poverty rate by almost 20 percentage points. The concentration of pensions around the basic amount leaves very little room for intra-pensioner redistribution. So the scheme must be financed by increasing the tax burden of the non-elderly. The situation in the UK is similar, where the provision of a minimum pension of $40 \%$ of earnings virtually eradicates poverty in old age. However, in this case there is some scope for financing this by reducing existing UK earnings related pensions.

The effectiveness of the minimum in reducing poverty in Denmark and the UK is due to the already near-comprehensive nature of the basic pension schemes in both countries. In Italy there are significant gaps in public pension provision, which are duplicated in the coverage of the minimum pension that we have simulated and make it, in some ways, less effective in this country than in the others. The latter might be exacerbated by the fact that in Italy a relatively high proportion of non-elderly persons live with and depend on the pensions received by elderly household members.

Breaking the link with past contributions, or finding ways of crediting noncontributors, would improve the distributional effects of the minimum in Italy. This may also have a beneficial effect in countries such as the UK where - under the minimum scheme as we have simulated it - many couples only receive one entitlement to a minimum payment because they have only one contributory pension between them. If each member of the couple had their own minimum entitlement it would be possible for the level to be lower while still protecting all elderly - singles and couples - from falling below the poverty line. This issue is relevant, to some extent, in each country examined and is particularly evident in the German case, as shown in Figure 6.

More generally there is an important aspect of pensions and pension reform that is missing from this paper: an analysis by gender. It is well known that women tend to have lower pension entitlements than men because of (on average) lower earnings and less of their 
lives spent in paid work, and that they are more likely to spend longer in poverty in old age. ${ }^{19}$ It is likely that the types of reform packages that we have considered would be to the net benefit of women, at least in the three countries that depend on contributory systems. ${ }^{20}$ Nevertheless, further analysis - which takes account of dependency and survivorship - is needed to establish the extent to which this is so.

The major challenge identified by most commentators is the growing pressure on the public finances due to pensions. So a critical issue is the cost of the reform in relation to its beneficial effects. We have explored revenue neutral packages as a way of illustrating the different trade-offs across systems and countries. In the future, if the dependency ratio is higher or private pension income has grown, the conditions will be different. The approach we have taken - exploring reform components individually and in combination - allows us to anticipate the effects of packages that are designed to raise revenue or release resources. For example, we can see from Table 5 that setting the minimum pension at 30\% rather than $40 \%$ of average earnings would release revenue corresponding to about $1 \%$ of average disposable income (more in Germany and the UK). ${ }^{21}$ Poverty reduction measured using FGT(2) would still be considerable and the fall in the poverty rate for the elderly still significant. More generally we have seen that the cost is relatively low if (a) the shortfall between the existing pension and the minimum level is small (Denmark, UK); (b) the numbers qualifying are small (Italy, Germany); or (c) the minimum pension replaces existing means-tested pensioner benefits (UK).

However, in assessing the balance between the fiscal costs and anti-poverty impacts it is important to acknowledge that our comparisons do not capture some important effects that may differ in significance across countries. For example, when increasing contribution rates we take no account of any effects on employment of increasing non-wage labour costs in this way. Likewise, we assumed that the proposed reforms do not affect the savings behaviour of the population. More generally we have assumed that there is no "leakage" of revenue from increases in contributions through evasion or the development of new avoidance mechanisms [Gillion et al. (2000); Manchester (1999)]. Similarly, we have also assumed that the minimum pension could be administered in such a way as to achieve $100 \%$ take-up. This may be possible where existing systems are not fragmented and where a single authority possesses all the information necessary to determine entitlement automatically, but perhaps not in other cases. Administrative functions and capacities differ across countries, as do cultural norms in relation to benefit claiming and tax paying. These aspects matter in practice and could be important factors in influencing the relative impact of actual reforms in different countries.

The main conclusion that can be drawn from this preliminary exercise is that the appropriate direction of reform is not the same across EU Member States. Even if there are long term goals in common, the most effective pathways are different. Furthermore, we have found conducting policy simulations that are in any way comparable across just four pension systems to be much more difficult than we anticipated. A note of caution is needed, not just in relation to estimates in this paper, but in any international comparisons of pension systems and the estimated outcomes of reforms. The value of a tax benefit model is to allow the

19 The need to address gender inequalities in pension incomes is explicitly recognised in EU-level policy statements as part of the pensions “modernisation” agenda. See for example European Council (2003, page 103).

20 Preliminary analysis seems to confirm this speculation; results available from the authors on request.

21 The interaction effect of reducing existing pensions would also need to be taken into account. 
examination of changes individually and in combination: each component can be considered in detail but at the same time taking account of interactions with other parts of the system. The value of a multi-country model such as EUROMOD is to allow these changes to be examined within a comparable framework which is capable of highlighting the existence of real differences.

\section{References}

Atella V., M. Coromaldi and L. Mastrofrancesco, 2001, “EUROMOD Country Report: Italy”, www.econ.cam.ac.uk/dae/mu/emodcty.htm

Atkinson A. B. and H. Sutherland, 1998, "Microsimulation and Policy Debate: a Case Study of the Minimum Pension Guarantee in Britain”, in Galler H. P. and G. G. Wagner (eds.), Empirische Forschung und wirtschaftspolitische Beratung - Festschrift für Hans-Jürgen Krupp zum 65 Geburtstag, Frankfurt and New York: Campus, 79-98.

Atkinson A. B., F. Bourguignon, C. O’Donoghue, H. Sutherland and F. Utili, 2002, "Microsimulation of Social Policy in the European Union: Case Study of a European Minimum Pension”, Economica, 69, 229-243.

Bardasi E., and S. Jenkins, 2004, “The gender gap in private pensions”, University of Essex, ISER Working Paper No 2004-29.

Dennis I. and A-C. Guio, 2003, "Poverty and social exclusion in the EU after Laeken- part 1", Statistics in Focus Theme 3 8/2003, Eurostat.

Economic Policy Committee, 2002, "Reform challenges facing public pension systems: the impact of certain parametric reforms on pension expenditure”, EPC/ECFIN/237/02.

Esping-Andersen G., 1990, The three worlds of welfare capitalism, Polity Press, Cambridge.

European Commission, 2003, “Draft Joint Inclusion Report: Statistical Annex”, [COM(2003)773final]

http://europa.eu.int/comm/employment_social/news/2001/jun/napincl_03_da_en.pdf

European Council (EC), 2003, "Joint report on adequate and sustainable pensions" http://europa.eu.int/comm/employment_social/soc-prot/pensions/2003jpr_en.pdf

Eurostat, 1996, The European Community Household Panel (ECHP): Survey methodology and implementation, Theme 3, Series E, Eurostat, Luxembourg.

Feldstein M. and H. Siebert (eds.), 2002, Social Security Pension Reform in Europe, University of Chicago Press, Chicago and London.

Ferrera M., 1996, “The 'Southern model' of welfare in Social Europe”, Journal of European Social Policy 6, pp. 17-37.

Foster J.E., J. Greer and E. Thorbecke, 1984, “A class of decomposable poverty measures”, Econometrica 52, pp. 761-766.

Gillion C., J. Turner, C. Bailey and D. Latulippe, 2000, Social Security Pensions: Development and reform, ILO, Geneva.

Grabka M., 2001, "EUROMOD Country Report: Germany", www.econ.cam.ac.uk/dae/mu/emodcty.htm

Hagenaars A.J.M., K. de Vos and M.A. Zaidi, 1994, Poverty statistics in the late 1980s: Research based on micro-data, Theme 3, Series C, Eurostat Luxembourg. 
Hancock R.M. and G. Barker, 2005, “The quality of social security benefit data in the British Family Resources survey: implications for investigating Income Support take-up by pensioners”, Journal of the Royal Statistical Society Series A 168, Part 1, 63-82.

Hansen H., 2001, "EUROMOD Country Report: Denmark", www.econ.cam.ac.uk/dae/mu/emodcty.htm

Immervoll H. and C. O'Donoghue, 2001, "Imputation of Gross Amounts from Net Incomes in Household Surveys: An Application using EUROMOD”, EUROMOD Working Paper EM1/01, University of Cambridge.

Immervoll H., C. O’Donoghue and H. Sutherland, 1999, “An Introduction to EUROMOD”, EUROMOD Working Paper EM0/99, University of Cambridge.

International Labour Office, 2001, Social Security: A new consensus, ILO, Geneva.

ISSAS, 1990, Poverty in figures: Europe in the early 1980s, Theme 3, Series C, Eurostat, Luxembourg.

Keenay G. and E. Whitehouse, 2003, "Financial Resources and Retirement in Nine OECD Countries: the Role of the Tax System”, OECD Social, Employment and Migration Working Papers No. 8, OECD:Paris.

Manchester J., 1999, “Compliance in social security systems around the world”, in O.S. Mitchell, R.J. Myers and H. Young (Eds.), Prospects for social security reform, Philadelphia: University of Pennsylvania Press.

Mantovani D. and H. Sutherland, 2003, "Social Indicators and other Income Statistics using the EUROMOD Baseline: a Comparison with Eurostat and National Statistics", EUROMOD Working Paper EM1/03, University of Cambridge.

Pensions Policy Institute (PPI), 2003, State Pension Models, PPI: London (www.pensionspolicyinstitute.org.uk)

Peracchi F., 2002, “The European Community Household Panel: A review”, Empirical Economics 27, pp. 63-90.

Sutherland H., 1998, “A Citizen’s Pension”, Microsimulation Unit Discussion Paper MU9804, Department of Applied Economics, University of Cambridge.

Sutherland H., 2001, "EUROMOD Country Report: United Kingdom", available from www.econ.cam.ac.uk/dae/mu/emodcty.htm

Tsakloglou P., 1996a, "Elderly and non-elderly in the European Union: A comparison of living standards”, Review of Income and Wealth 42, pp. 271-291.

Tsakloglou P., 1996b, “On the relative welfare position of older persons in the member-states of the European Union”, in C. Paraskevopoulos, R. Grinspun and T. Georgakopoulos, (eds.) Economic Integration and Public Policy: NAFTA, EU and beyond, Edward Elgar, Cheltenham.

Weller C. E., 2004, “The future of public pensions in the OECD”, Cambridge Journal of Economics, 28, pp. 489-504.

World Bank, 1994, Averting the Old Age Crisis: Policies to Protect the Old and Promote Growth, Oxford University Press, Oxford. 
Appendix 1.

EUROMOD base datasets

\begin{tabular}{|c|c|c|c|c|}
\hline Country & $\begin{array}{l}\text { Base Dataset for } \\
\text { EUROMOD }\end{array}$ & Type & $\begin{array}{l}\text { Date of } \\
\text { collection }\end{array}$ & $\begin{array}{l}\text { Reference time } \\
\text { period for } \\
\text { incomes }\end{array}$ \\
\hline Denmark & $\begin{array}{l}\text { European Community } \\
\text { Household Panel (W2) }\end{array}$ & ECHP & 1995 & annual 1994 \\
\hline Germany & $\begin{array}{l}\text { German Socio-Economic } \\
\text { Panel (W15) }\end{array}$ & National Panel & 1998 & annual 1997 \\
\hline Italy & $\begin{array}{l}\text { Survey of Households } \\
\text { Income and Wealth }\end{array}$ & Income survey & 1996 & annual 1995 \\
\hline UK & $\begin{array}{l}\text { Family Expenditure } \\
\text { Survey }\end{array}$ & Household Budget Survey & $1995 / 6$ & $\begin{array}{l}\text { month in } \\
1995 / 6\end{array}$ \\
\hline
\end{tabular}




\section{Appendix 2. \\ A short description of the pension systems of Denmark, Germany, Italy and the UK}

\section{Denmark $^{22}$}

The basic old age pension is a tax financed pay-as-you-go scheme based on length of residence and citizenship rather than former income or contribution record. The maximum pension is paid on the basis of residence from the age of 15 until retirement at the age of 67 years (reduced to 65 in 2004). For residence of less than 40 years the pension is paid on a pro rata basis.

Danish early retirement schemes depend on voluntary contributions to the unemployment insurance have no influence on the old-age pension. This cannot be claimed before the age of 67 and there is no premium for delaying retirement.

In 1998 the residence based old-age pension consisted of 3 flat rate benefits.

1. a 'basic amount' of 46,812 DKK (annual basis) which is received by all pensioners; this is means-tested on current earnings . However, 95\% receive the full basic amount (PPI, 2003). .

2. a 'supplement' which is 39,576 DKK for singles and 20,568 DKK each member of a couple; this is means-tested on income from earnings and capital of both partners with a threshold of 43,900 DKK for a single and 88,000 DKK for a couple. The taper is 30 per cent for income above the thresholds. For couples where both spouses are old-age pensioners the taper is 15 per cent for each. In 2002 64\% received the supplement in full (EC, 2003).

3. a 'special supplement' of 6,828 DKK for singles (not means tested).

The "general contribution" and the "temporary pension contribution" are direct components of the income tax scheme. They are levied at a rates of $8 \%$ and $1 \%$ respectively on all gross wages and taxable fringe benefits, and the part of the business income that is categorised as personal income.

In addition, there is a social insurance supplementary pension ("ATP"). Contributions are compulsory for employees working at least 9 hours a week. Pensions are paid depending on the number of contributions and hours of work: they are not earnings-related. If a pensioner had worked full time since 1964 when the scheme was established the maximum payable would be 16,620 DKK. Some 68\% of pensioners receive some ATP (PPI, 2003). This is financed by a contribution, a third of which is paid by employees themselves (the remainder by employers). The own contribution in 1998 was 894 DKK on an annual basis for full time work (27 or more hours per week), for a working week between 18 and 27 hours the rate was 2/3 and for a working week between 9 and 18 hours it was 1/3.

All contributions are deductible from income for personal income tax purposes.

Private pension schemes do exist, and cover $80 \%$ of the current employed workforce but are not yet widespread as pensions in payment.

Within an EU perspective the pension system has been categorised as having a replacement rate that is "low" but public finances that are "sustainable". (Economic Policy Committee, 2003; Table 5.1). The main policy challenge is seen as increasing the replacement rate through greater occupational scheme coverage (EC, 2003). 


\section{Germany $^{23}$}

Germany operates a contributory pay-as-you-go earnings-related state pension. Pension contributions to social insurance are paid half each by employers and employees at a combined rate of $20.3 \%$ of salary up to a ceiling. The ceiling and the average pension payments are different in the former West and East Germany. The contribution assessment limit in 1998 was DM 8,400 a month in western Germany and DM 7,000 in eastern Germany. Pension payments are also partially subsidised to allow the system to cover people who have been carers.

Pensions can be taken early or deferred beyond the pension age of 65, with a corresponding adjustment to benefit. The self-employed can make voluntary contributions. There are no additions for dependants.

In addition, voluntary company schemes cover about half of men (fewer women) and personal pensions (with tax incentives) cover $21 \%$ of male and $9 \%$ of female pensioners (PPI, 2003).

There is no minimum pension. Social assistance is paid to $1.4 \%$ of pensioners (PPI, 2003). This acts as a top-up to other incomes.

Within an EU perspective the pension system has been categorised as having a replacement rate that is "Medium" and public finances that are "at risk". (Economic Policy Committee, 2003; Table 5.1). The main challenge is in "maintaining financial sustainability in the face of an expected doubling of the ... dependency ratio" (EC, 2003, page 118).

\section{Italy $^{24}$}

The Italian state pension system is in the process of transformation. In the longer run the intention is to mimic a funded scheme by making pensions depends on lifetime contributions and aggregate life expectancy and growth. In 1998 the main contributory pension (made up of many similar but distinct schemes) was earnings-related based on contributions up to a maximum ceiling. Reference earnings were the last 10 years and the proportion of pension that is assessed in this way is being gradually reduced as the reforms are phased in, replaced by whole working lives.

Retirement could be taken early, and also deferred, but only to 65 .

Where entitlement to this pension is below a certain limit ("pensione minima", minimum pension), pensioner is eligible for a means tested supplement ("integrazione al minimo") up to the difference between that limit and the actual entitlement. Relevant income limits are at individual and couple level. Full supplement is paid if personal taxable income is lower than minim pension and couple income is lower than four times minimum pension, a taper of $100 \%$ is applied to higher incomes. This affects about $39 \%$ of people aged $65+$.

The Social Pension (now known as "assegno sociale" or social allowance) is a means-tested minimum income scheme which covers about $6 \%$ of elderly who do not have contributory rights.

\footnotetext{
23 See Grabka (2001) and MISSOC for 1998 [http://europa.eu.int/comm/employment_social/socprot/missoc98/english/07/index.htm]

24 See Atella et al (2001).
} 
There are also some occupational defined contribution schemes and some personal tax incentivised schemes that are not very widespread. EUROMOD estimates show that just 1\% of current elderly receive such income (Table 2).

Within an EU perspective the Italian pension system has been categorised as having a replacement rate that is "High" and public finances that "appear to be sustainable" but conditional on debt being reduced. (Economic Policy Committee, 2003; Table 5.1).

\section{United Kingdom ${ }^{25}$}

The state system was in 1998 made up of (a) a flat rate contributory pension (the "basic pension"), (b) a state earnings-related component, (c) occupational and personal pensions that are regulated and may substitute for the state earnings related pension and, for pensioners whose income falls below a certain level, (d) a minimum income scheme.

If they meet the contribution conditions (44 years for men; 39 for women in 1998) people over state pension age get a flat rate basic pension. If conditions are only partly met, a reduced pension of at least $25 \%$ of the basic can be paid. Spouses who do not meet the conditions may receive a lower pension based on their partner's contributions. At age 80 contribution conditions are removed. There is no early retirement; extra pension increments can be earned if retirement is delayed. Additions are paid for dependent spouses under pension age (subject to a means test) and dependent children. The basic pension is taxable.

For pensioners who contributed to the State Earnings Related Pension Scheme (SERPS) an additional earnings-related pension is payable. This is taxable and there are no additions for dependants.

Income Support (IS) is the main social assistance benefit for people whose family incomes are lower than a specified level and who are not in work for 16 or more hours per week. If family income is less than this amount, IS makes up the shortfall. The applicable amount is made up of personal allowances and premiums for certain groups with special needs. The level of payment of the basic pension is less than the income level offered by IS. Unless they or their partners have other sources of income a basic pensioner will be entitled to a top-up from IS.

Social contributions, known as National Insurance contributions (NICs), finance current National Insurance (NI) benefits including the NI basic retirement pension. Employees pay contributions on their current weekly earnings between a lower and upper earnings limit. Employees who are contracted out of SERPS pay a lower rate of contribution. People with self-employment income are liable for contributions which only bring entitlement to the basic retirement pension, not to any earnings related benefit.

National Insurance contributions are not tax-deductible.

Within an EU perspective the British pension system has been categorised as having a replacement rate that is "Low" and public finances that are "sustainable". (Economic Policy Committee, 2003; Table 5.1). The main policy challenge is seen as the need to increase the replacement rate through more extensive private pension coverage. 
Appendix 3. Position of (a) pensioners and (b) people aged 65+ (“elderly") in the EUROMOD distribution of household equivalised disposable income

\section{(a) pensioners}

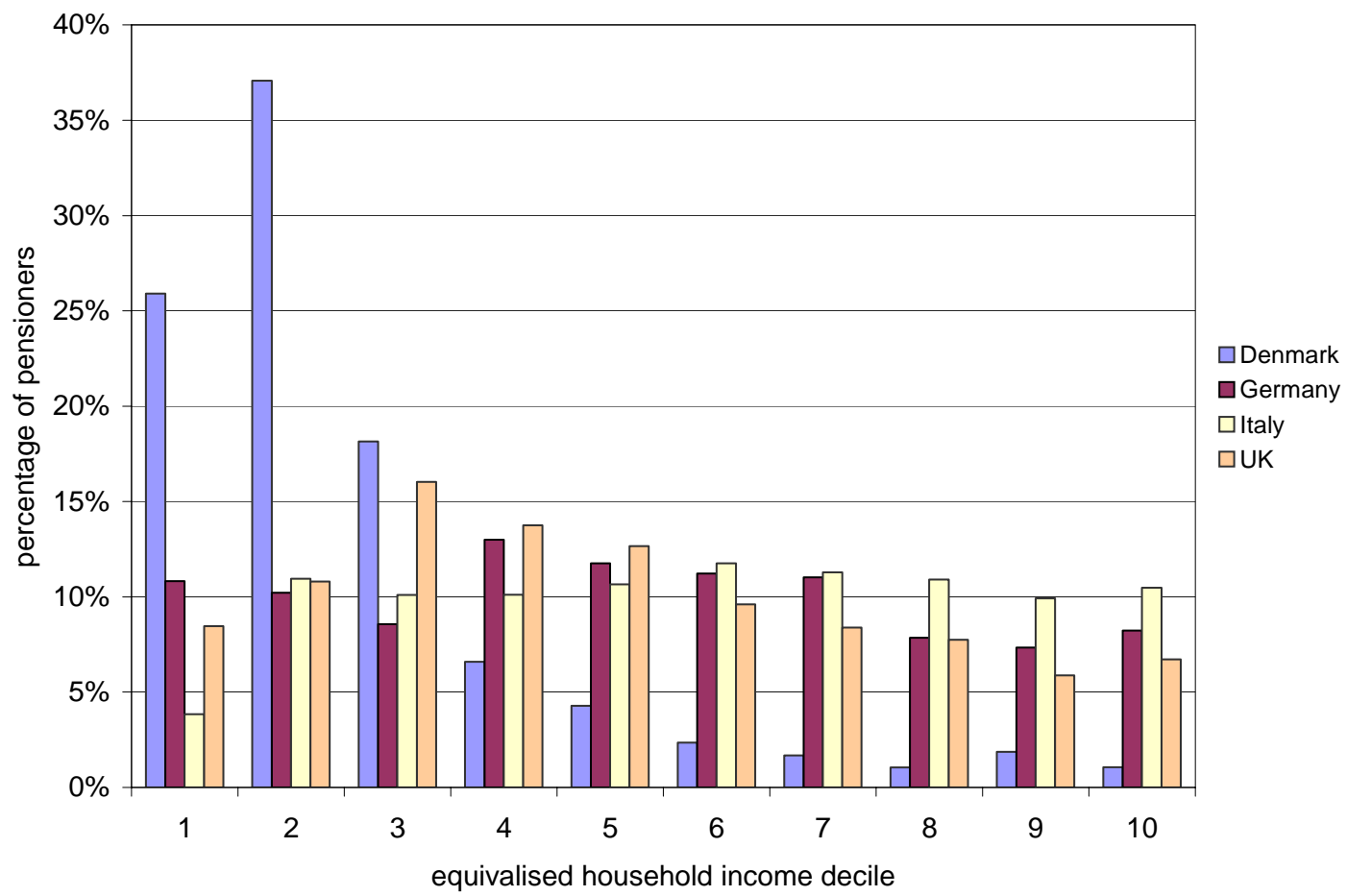

(b) elderly (65+)

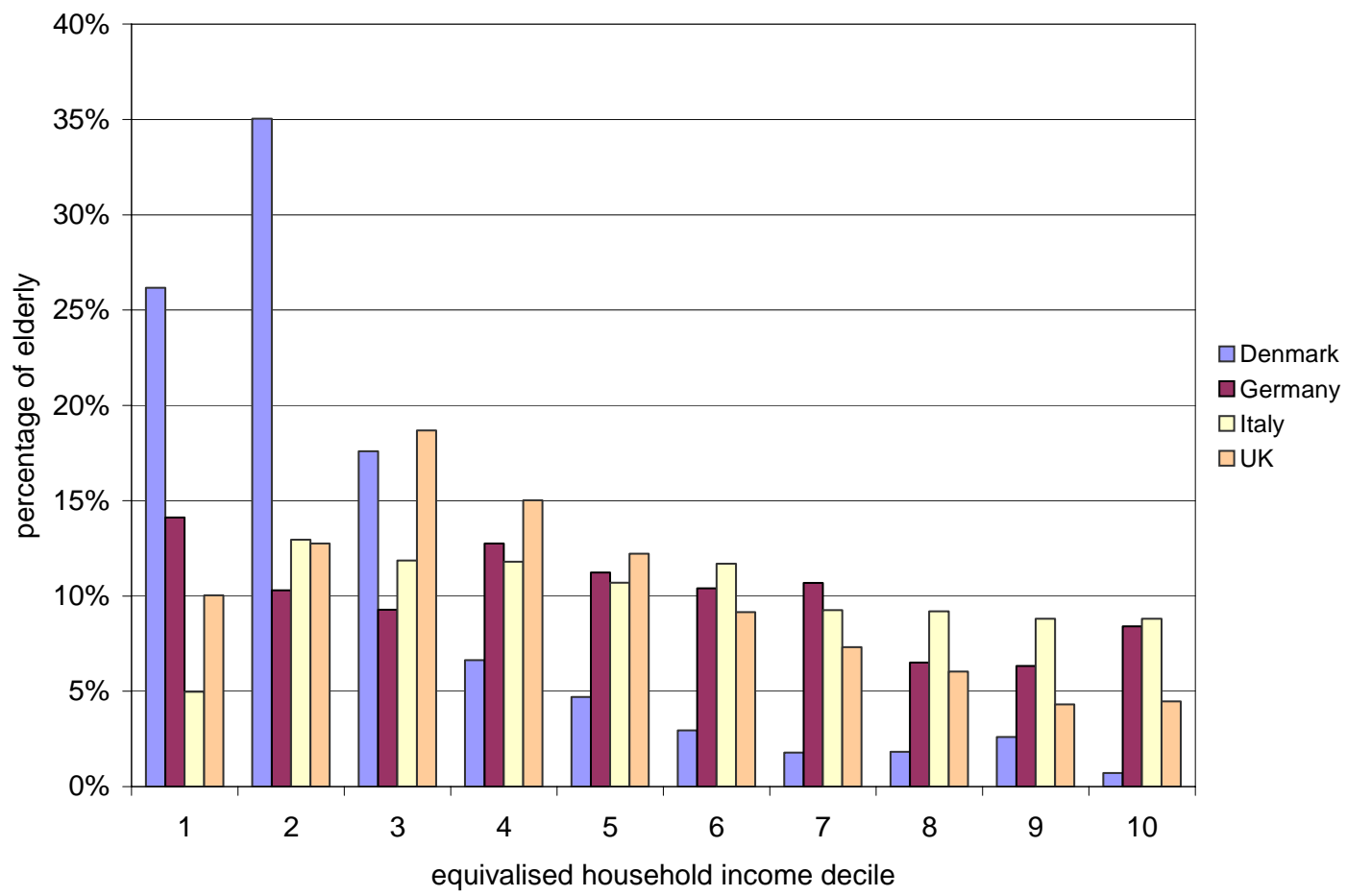

Source: EUROMOD 